\title{
LA AUTONOMÍA PRIVADA Y LOS DERECHOS FUNDAMENTALES. LOS INTERESES GENERALES, MANDATO CONSTITUCIONAL
}

\author{
ANTONIO LÓPEZ PINA \\ Catedrático de Derecho Constitucional \\ Universidad Complutense de Madrid
}

SUMARIO

I. La autonomía privada y los derechos fundamentales.

II. Visión del interés general como una mera cuestión de competencia.

III. De derechos subjetivos a garantías institucionales. Presupuestos constitucionales para la determinación material de los intereses generales.

Apostilla. En particular, la lengua castellana como lengua española oficial del Estado condición material para el ejercicio de las libertades.

Epílogo.

"Derecho natural del hombre hay uno únicamente, la libertad", decía Kant en La Metafísica de las Costumbres ${ }^{1}$. Qué hacer, para que en una sociedad igualitaria de gobierno popular impere la libertad y no el despotismo es el problema público, al que, según Tocqueville, toda sociedad contemporánea está convocada a dar respuesta².

1 Cfr.: Immanuel Kant, Die Metaphysik der Sitten, Werkausgabe Bd. VIII Hrgbn. von Wilhelm Weischedel, Frankfurt am Main: Suhrkamp 1982.

2 Cfr.: Alexis de Tocqueville, De la Démocratie en Amérique, Paris: Editions Gallimard, 1961; id., L'ancien régime et la révolution, Paris: Gallimard, 1952. 
Y es el caso que, en la España de hoy, antes que a la pacífica e igual libertad de todos bajo el Derecho como reflejo de la primacía de los intereses generales, asistimos perplejos a negaciones en cadena, por españoles libres, del bien y de las libertades de los otros: de los enfrentamientos partidarioconfesionales y mediáticos a la exacerbación de toda suerte de populismos hasta el borde de la violencia; de una espiral de reivindicaciones territoriales lejos de toda mesura a expectativas insaciables de lucro y de consumo en medio de un desarrollo económico no sostenible. Sin embargo, nuestra sociedad no puede sin grave riesgo continuar por más tiempo a la deriva. Entre tanto desafuero y extravío, no se me alcanza mejor expediente para recuperar el norte que volver sobre nuestra Constitución, como manifiesto de la libertad alumbrado en un momento excepcional de luces de la España contemporánea.

Al respecto, tengo para mí que nuestra arquitectura constitucional arranca, en primer lugar, de la autonomía privada, de la que son elementos esenciales la propiedad privada y la libertad empresarial. Ahora bien, para que la libertad de cada uno sea conciliable con las de los demás, deberá ser limitada, plegándola a la primacía de los intereses generales. Y, así, el texto constitucional levanta como barreras a la autonomía privada, de un lado, la vertiente objetiva de los derechos fundamentales y los principios rectores de la política social y económica (arts. 39-52 CE). De otro, como cláusula constitucional específica, el postulado de la subordinación de la riqueza al interés general (art. 128 CE). En conjunto, alzan los intereses generales como clave de bóveda del orden jurídico.

Para evitar que la coyuntura pueda dar apariencia de aldabonazo a mi mero relatar unas cuantas verdades, me esforzaré en decirlo con guante de seda; no más, pues, que una invitación al retorno de todos a la concordia constitucional, a la que desde siempre nos llama Landelino Lavilla ${ }^{3}$.

\section{LA AUTONOMÍA PRIVADA Y LOS DERECHOS FUNDAMENTALES}

La autonomía privada (arts. 10.1; 17 en conexión con art. 1.1 CE) es la expresión originaria de la libertad. Sobre tal postulado, un pasaje cincelado por Böckenförde vale por todo un libro clásico de texto: A la distinción entre Estado y sociedad subyace la idea del individuo que se autogobierna, cuya autonomía respecto del Estado debe ser preservada. A él sirve la dicotomía de libertad privada y vinculación estatal. Ello da lugar a un reparto de las justificaciones: no es el individuo que ejerce su libertad el que ba de dar razón de ello; es el Estado que interviene en tal derecho de libertad el que ha de justificarse. El Estado tiene encomendadas tareas limitadas, en

3 cfr.: Landelino Lavilla, Política de la Memoria, Discurso de Recepción, Sesión de 12 de diciembre de 2006, Madrid: Real Academia de Ciencias Morales y Políticas. 
particular la garantía de la paz, la seguridad y la libertad. Las intervenciones del Estado en la libertad individual solamente serán, así, válidas, en la medida que sean necesarias para satisfacer tales tareas; sólo con tal reserva estamos dispuestos a otorgar al Estado la competencia sobre la competencia ${ }^{4}$.

En otras palabras, los derechos fundamentales formalizan la dicotomía, por principio, de libertad para el individuo y acción reglada para los poderes públicos. Para los privados se crea una franquicia de autonomía libre de Derecho (arts. 10.1; 17 CE), para lo público se fija una vinculación al Derecho (arts. 9.1; 103 CE). Mientras para los particulares el Derecho incide sólo definiendo externamente los límites de lo que es lícito (art. 25 CE), los poderes públicos disponen de menos discrecionalidad, habiendo de actuar conforme a un principio reglado de competencia y responsabilidad; la disposición de los órganos del Estado sirve simultáneamente como mecanismo de limitación funcional del poder público.

El amplio ámbito de libertad individual configurado mediante los derechos fundamentales por la Constitución cobra expresión en el art. 10. 1 CE, como derecho general de libertad y rúbrica de todos los derechos. Tal libre desarrollo de la personalidad comporta el derecho de cada individuo, al fin de la mejor realización personal, a hacer y dejar de hacer a voluntad a tenor de las propias capacidades 5 . Los ámbitos especiales de la autonomía privada garantizados constitucionalmente son comprendidos por cada uno de los derechos fundamentales en concreto: así, el art. 33 CE protege la propiedad, el art. 38 CE la libertad empresarial, el art. 27 CE la educación, el art. 20 CE la libertad de expresión, el art. 16 CE la libertad de pensamiento y religiosa, el art. 35 CE la libertad profesional y de trabajo, el art. 28 CE en conexión con el art. 22 CE la libertad sindical, el art. $24 \mathrm{CE}$, en fin, la tutela judicial.

Ahora bien, desde el principio, autonomía privada significa más que la mera defensa frente a intervenciones del Estado limitadoras de los derechos individuales. La autonomía privada solo puede ejercerse si existe un orden jurídico del Estado que reconoce como vinculante lo contractualmente querido y hace posible que se lleve jurídicamente a la práctica. El tráfico jurídico privado no puede discurrir en un espacio no reglado por el Estado: el interés individual conlleva, así, de un lado, que el tráfico discurra libremente sin intervención estatal y, de otro, que una regulación pública haga posible el ejercicio de la libertad.

Adicionalmente, más allá de asegurar al individuo un ámbito de libertad frente al Estado, los derechos fundamentales garantizan al particular frente a

4 vid., Ernst-Wolfgang Böckenförde, Die Bedeutung der Unterscheidung von Staat und Gesellschaft im demokratischen Sozialstaat der Gegenwart, in ders. Staat, Gesellschaft, Freiheit. Studien zur Staatstheorie und zum Verfassungsrecht, Frankfurt am Main: Suhrkamp, 1976.

5 vid. en particular BVerfGE 6, 32 (36 f.); asimismo I. Gutiérrez, Dignidad de la persona y derechos fundamentales, Madrid: Marcial Pons Ediciones Jurídicas, 2005; D. Grimm, Constitucionalismo y derechos fundamentales, Estudio Preliminar de A. López Pina, Madrid: Ed. Trotta, 2006; A. López Pina e I. Gutiérrez, Elementos de Derecho público, Madrid: Marcial Pons Ediciones Jurídicas, 2002 
terceros un derecho a protección por el Estado. Tal dualismo da cuño al Derecho privado: la sociedad se constituye por medio del Derecho civil (Herzog) ${ }^{6}$; sobre los pilares de la propiedad privada, la libertad de empresa, la libertad de contratar y de invertir y la libertad profesional y de trabajo se constituye y actúa la sociedad civil. Si los arts. 10.1, 33, 387, 35.1 y 28 CE garantizan la autonomía privada, contienen asimismo una encomienda de protección y regulación para el legislador. Dotada de los derechos fundamentales como facultades subjetivas y amparada por la obligación de protección a cargo del Estado, la autonomía privada aparece así como pieza estructural de un orden social en libertad.

De todos modos, desde $\mathrm{Hegel}^{8}$ hemos cobrado conciencia de que, por benéficas que sean la libertad y la autonomía privada, abandonadas a sí mismas son causa de servidumbres y de grandes desigualdades; una autonomía privada y un ejercicio de la libertad sin límites acaban, justo, en la negación de la libertad de los otros, cuando no provocan conflictos de tal envergadura que hacen estallar la sociedad. Todo el edificio dogmático de los derechos fundamentales arranca, ciertamente, de una vigorosa concepción de los mismos como derechos subjetivos. Pero un desproporcionado individualismo, de escasa sensibilidad para la vida en común, ha sido el correlato de tan unilateral punto de partida.

De ahí que los derechos fundamentales vengan a delimitar la relación entre la esfera privada y la esfera pública en un doble sentido: si aquellos limitan la intervención del Estado, el interés público justifica, a su vez, la limitación de los derechos subjetivos. Los derechos fundamentales no son, así, garantizados sin límites. Más bien existen intereses generales ${ }^{9}$ que justifican, a

6 cfr.: Herzog, in Maunz / Dürig, Art. 20 Rn I 46.

7 SSTC 227/1993; 124/2003

8 El trabajo, no la propiedad, es el concepto central en torno al cual se articula la nueva sociedad que nace de la revolución industrial. El trabajo genera nuevas relaciones sociales; la división del trabajo se traduce en la institución del mercado, que rige la sociedad de trabajadores en la medida en que determina qué, cuánto y cómo producir para satisfacer las necesidades. El mercado, liberador del vasallaje del régimen feudal, deviene simultáneamente un poder impersonal y despótico sobre los trabajadores que sufren no solamente de la alienación sino asimismo de crecientes desigualdades. En tales procesos, la desintegración acaba siendo más fuerte que los procesos integradores de la sociedad civil. Ciertamente, como precio de la ganada libertad han saltado las contradicciones de las comunidades primitivas. Pero no solamente: las fuerzas integradoras del trabajo no han acertado a reemplazarlas. Como consecuencia, las tensiones sociales prevalecen en el nuevo sistema de necesidades, la sociedad amenaza con estallar. La libertad y la integración social solo caben finalmente en el seno del Estado, como instancia moral superior a la sociedad integradora de lo que el sistema de necesidades ha desintegrado. Hegel, Grundlinien der Philosophie des Rechts, \& \& 182-208 Berlin: Akademie Verlag, 1956.

9 cfr.: El tema fue objeto de las obras, Ulrich K. Preuss, Zum staatsrechtlichen Begriff des Öffentlichen, Stuttgart: Ernst Klett Verlag 1969; Peter Häberle, Öffentliches Interesse als Juristisches Problem, Bad Homburg: Athenäum Verlag, 1970; 2. Auflage mit Nachtrag, Berlin: Duncker \& Humblot, 2005.

Recientemente han vuelto sobre el mismo Robert Uerpmann, Das öffentliche Interesse, Tübingen: Mohr Siebeck Verlag, 1999; Gemeinwohl und Gemeinsinn im Recht. Konkretisierung und 
su vez, la limitación de aquéllos por el Estado. En este sentido Schnapp ${ }^{10}$, en la doctrina alemana, caracteriza como mecanismo de equilibrio de los intereses particulares y los intereses generales la doble estructura, de un lado, de protección de los derechos y, de otro, de justificación de las limitaciones de los mismos. En el bien entendido de que intereses privados e interés publico no constituyen compartimentos estancos; son categorías para la búsqueda de un orden en el que la voluntad de cada uno sea conciliable con la voluntad de los demás bajo una ley general de libertad (Kant) ${ }^{11}$.

¿Qué entiendo por intereses generales? El art. 128 CE subordina toda la riqueza de España al interés general; conforme al art. 103 CE la Administración Pública sirve a los intereses generales ${ }^{12}$. Interés público o interés general son conceptos que se implican recíprocamente y cuyo uso depende del contexto: en contraposición a propiedad privada, mercado, iniciativa privada, sector privado o interés privado hablamos de interés general; frente a los intereses particulares hablamos de interés público. El concepto jurídico del interés general o interés público remite, en principio, al deber del Estado de realizarlo. De todos modos, al no precisar el texto constitucional su contenido, interés público o interés general son conceptos jurídicos indeterminados, no susceptibles de ser aplicados sin más. Dogmáticamente, se trata de conceptos normativos abiertos a la ocupación ideológica, que precisan ser dotados de contenido. Los fines del Estado se nos brindan, así, al fin de orientarlos y medirlos. De esta manera, el interés público o el interés general deviene un concepto bisagra que si, de un lado, remite a la legitimación del Estado, fines y tareas del Estado incluidas, de otro, transpone las mismas al plano constitucional y las proyecta al orden jurídico.

La tarea del Estado de procurar el interés general se traduce en la puesta a disposición y el fomento de bienes públicos ${ }^{13}$. Cuentan como públicos los bie-

Realisierung öffentlicher Interesen, Herfried Münkler; Karsten Fischer Hrsg., Berlin: Akademie Verlag, 2002; Gemeinwohl in Deutschland, Europa und der Welt, W. Brugger; S. Kirste; M. Anderheiden Hrsg., Baden-Baden: Nomos Verlagsgesellschaft, 2002.

En España son pioneros los trabajos El interés público en la interpretación de los contratos administrativos, Documentación Administrativa, n. ${ }^{\circ}$ 110, 1967, de Landelino Lavilla, La Administración sirve con objetividad los intereses generales, Libro-Homenaje a Eduardo García de Enterría, Madrid: Ed. Civitas, 1992, de Alejandro Nieto y Lo público como supuesto constitucional, México: Universidad Nacional Autónoma de México, 1997, de Antonio de Cabo de la Vega.

Sobre las fuentes clásicas del concepto de intereses generales en términos de bien común cfr.:, Erns-Wolfgang Böckenförde, Gemeinwohlvorstellungen bei Klassikern der Rechts-und Staatsphilosophie, in: Gemeinwohl und Gemeinsinn im Recht. Konkretisierung und Realisierung öffentlicher Interesen, Herfried Münkler; Karsten Fischer Hrsg., Berlin: Akademie Verlag, 2002; en la doctrina española, por todos Rodrigo Fernández-Carvajal, El Lugar de la Ciencia Política, Murcia: Universidad de Murcia, Secretariado de Publicaciones, 1981.

10 vid. Schnapp, Juristische Schulung, 1978, S. 729.

11 cfr.: Kant, Die Metaphysik der Sitten, op. cit.; Michael Stolleis, Verwaltungsarchiv, 65 (1974). 12 vid. Alejandro Nieto, op. cit.

13 cfr.: Michael Anderheiden, Gemeinwohlförderung durch die Bereitstellung kollektiver Güter in: Gemeinwohl in Deutschland, Europa und der Welt, W. Brugger; S. Kirste; M. Anderheiden Hrsg., Baden-Baden: Nomos Verlagsgesellschaft, 2002. 
nes que, a diferencia de los privados, no pueden ser producidos y distribuidos por el mercado; más bien, deberán ser procurados por el Estado. Estos bienes poseen rasgos comunes que han permitido que se los caracterice como públicos, en la medida en que son de acceso universal y no desaparecen por el mero consumo. Se distinguen por el rasgo de que ningún privado puede excluir a nadie de su utilización. El mandato constitucional del interés general deberá ser concretado al caso en la determinada situación de que se trate. Así aplicados, el interés general, el interés público, los intereses generales como mandato constitucional dejan de ser un concepto comodín a disposición de definiciones partidarias.

La cuestión es: ¿qué configuración de los mismos contiene la Constitución? Formalmente, buena parte de la doctrina y de la jurisprudencia los contempla como una simple cuestión de competencia, como a continuación veremos. Lo que sucede es que, sin perjuicio de definir la distribución de competencias, la Constitución contiene también parámetros materiales para definir el interés público o el interés general. De ahí que, si bien nos venga impuesto hacer las consideraciones a renglón seguido, nos esté vedado cerrar con ellas nuestro tema.

\section{VISIÓN DEL INTERÉS GENERAL COMO UNA MERA CUESTIÓN DE COMPETENCIA}

$\mathrm{Al}$ respecto, cabe ver el interés general como una cuestión de distribución de competencias: a saber, cuál es la instancia pública competente para definir qué sea y en qué consista el interés general. Así, dice el jurista alemán Uerpmann, lo determinante no son los intereses de una generalidad, sino las facultades del órgano competente en cada caso para decidir ${ }^{14}$. O bien, en términos del colega Ossenbühl, interés público es aquello que la instancia competente en un procedimiento válido y en observancia de los límites constitucionalmente establecidos declara como intereses generales ${ }^{15}$.

Tales autores creen ver, sobre el telón de fondo del orden competencial, los rasgos concretos del concepto del interés general. El interés público se ofrece entonces como instrumento para estratificar complejos procesos de decisión en el marco del régimen competencial y atribuir a determinados órganos las consiguientes facultades de definición. Y, efectivamente, la Constitución contiene las bases de la distribución de competencias sobre el interés público. En tal orden, el legislador tiene un lugar central; quien, por otra parte, influye en la distribución de competencias entre la Administración Pública y la Jurisdicción: más aún, la vinculación a la ley impone a jueces y funcionarios presupuestos del interés general en la aplicación del Derecho. Cuando el interés general está referido en el tipo de una norma, el legislador asigna la

14 vid. Robert Uerpmann, op. cit.

15 vid. Fritz Ossenbühl, Die öffentliche Verwaltung, 1970, 84 (87). 
competencia a jueces y tribunales. Cuando, en cambio, la interpretación del interés general es confiada a la discrecionalidad de la Administración Pública, el legislador está desposeyendo, en primera instancia, a los jueces de tal facultad. Todo ello en el bien entendido de que, de ordinario, la concreción del interés general requiere la concertación de más de un órgano del Estado: más bien suele tratarse de competencias graduales de concreción, con las que se escalona entre la Constitución, el legislador y los operadores jurídicos la definición del interés general.

Consiguientemente, el interés público no es, para sectores de la doctrina y cierta jurisprudencia, determinado material, sino procedimentalmente ${ }^{16}$ : decisivo para la definición del interés general es quién defina el interés y asuma su defensa y realización. Desde aquí se alza el puente dogmático hasta el régimen representativo de nuestra democracia. La definición y defensa del interés general corresponde a los órganos estatales ${ }^{17}$. Lo que no empece, a que la distribución territorial de poderes en nuestro Estado de las Autonomías asigne también a los órganos de las mismas competencias de concreción del interés general ${ }^{18}$. En caso de competencias compartidas, la definición estatal del interés general, destinado a ser concretado por las Comunidades Autónomas, prevalece en caso de conflicto sobre las decisiones de éstas. De todos modos, como regla común, todos los poderes públicos concurren a la definición, concreción y garantía de los intereses generales.

Siendo todo ello impecable doctrina constitucional, se queda a mi juicio, sin embargo, a medio camino. Nuestra jurisprudencia no ha sido siempre rectilínea y unívoca: y, si bien no ha dejado de tallar uno tras otro bienes públicos limitadores de los derechos fundamentales, como más adelante vamos a ver, en un sin fin de sentencias, en cambio, el Tribunal Constitucional reduce el interés público o el interés general al deslinde de competencias o cae en la tentación de interpretar la Constitución en defensa de concretos intereses territoriales ${ }^{19}$. En ocasiones evidencia su impotencia dogmática, dejándose enre-

16 Por todos, vid. Robert Uerpmann, op. cit.

17 "la tutela de los intereses públicos generales comprende por definición a los órganos estatales" (STC 25/1981).

18 La distribución territorial de poderes en nuestro Estado de las Autonomías asigna competencias de concreción de los intereses generales. la Constitución y los Estatutos son las únicas fuentes del orden constitucional de competencias (SSTC 113/1983; 28/1993). Sobre criterios constitucionales y estatutarios de reparto de competencias SSTC 252/1988; 76/1991; 236/1991; 79/1992.

19 vid., Ley sobre Centros de contratación de cargas en transportes terrestres de mercancías del Parlamento Vasco (STC 37/1981), Ley de regulación de estructuras comerciales y ventas especiales del Parlamento de Cataluña (STC 88/1986), Ley de Comercio interior del Parlamento de Cataluña, Ley de costas y Reglamento de desarrollo y ejecución (SSTC 149/1991; 198/1991), Ley de Ordenación del Comercio y Superficies comerciales de las Cortes Valencianas (STC 225/1993), Ley de Comercio Interior del Parlamento de Cataluña (STC 284/1993), Ley de Protección y Armonización de usos del Mar Menor (STC 36/1994), Ley de ordenación de los Transportes terrestres de las Cortes Generales (STC 118/1996), Real-Decreto Ley de Subvenciones y Ayudas del Estado a la Mejora de la eficacia de las estructuras agrarias (STC 128/1999), Leyes de Ordenación y Protección de las Areas Naturales de Interés especial y de Declaración de "Sa Punta de N.amer" como área natural de 
dar en el galimatías competencial de la distribución territorial de poderes o no viendo más allá de la conveniencia de volver sobre el tema de las fuentes del Derecho. A título de ilustración, contrástense los Casos Ley de Bases de Sanidad Nacional STC 83/1984; Ley reguladora de los Servicios de las Oficinas de Farmacia STC 109/2003; Ley de Ordenación Farmacéutica STC 152/2003, sobre limitaciones para el establecimiento de oficinas de farmacia con el Apothekenurteil, (sentencia sobre las Farmacias) de 1958, o el Müblengesetzurteil (decisión sobre la Ley de los Molinos) del Tribunal Constitucional alemán. En lo que procesalmente ha sido planteado como un conflicto de competencias entre el legislador estatal y determinadas Comunidades Autónomas, nuestros Magistrados consideran constitucionalmente conformes resoluciones administrativas denegatorias de autorización para la apertura de oficinas de farmacia. La validez de disposiciones reglamentarias se justifica por la legitimidad de los órganos públicos para disciplinar la libertad empresarial. En el fondo, por más que en algún caso el Tribunal haga alusión retórica al interés público o a los intereses generales, reduce el contencioso sea a un conflicto de competencias, sea a un pretexto para hacer una disquisición sobre las fuentes del Derecho - para nuestros Magistrados se trata solamente de una cuestión de legalidad.

En cambio, el Bundesverfassungsgericht declara: el derecho fundamental de la libertad profesional (art. 12.1 GG) debe proteger la libertad del individuo; la reserva de regulación debe garantizar la protección suficiente de los intereses generales" ${ }^{20}$. En tal sentido, define la sanidad pública como "un importante bien público", cuya protección puede justificar limitaciones de la libertad profesional del individuo. En relación con la Müblengesetz, el Tribunal consideró "el aseguramiento de la alimentación popular" como un interés público de alto rango, cuya protección justifica la limitación por el Estado de la libertad profesional ${ }^{21}$. En ése como en otros casos, el Tribunal alemán decide, más bien, un conflicto entre los intereses particulares de la libertad profesional y los intereses públicos.

Ciertamente, hemos establecido en 1978 una distribución territorial del poder tan ambigua que, a fuer de garantizar la diversidad, fomenta la litigiosidad. Que el régimen territorial haya funcionado hasta cierto extremo hay que agradecerlo a la labor del Tribunal Constitucional. Éste ha convertido el conflictivo modelo

especial interés (STC 248/2000), Ley sobre Régimen de Suelo y Valoraciones (STC 164/2001), Ley de ordenación del comercio minorista (STC 124/2003), Ley de la Función Pública de la Administración de la Generalidad (STC 101/2006)Si y cuando la jurisprudencia logra deslindar el conflicto de competencias, deja pendiente de resolver la cuestión nuclear de la materialidad constitucional de los intereses generales. Cuando tan fácil habría sido seguir la STC 48/1981 que hablaba de que "bases" (art. 149.1.13. ${ }^{a}, 18 .{ }^{a}$ y 25. ${ }^{a} \mathrm{CE}$ ), "Condiciones básicas" (art. 149.1.1. ${ }^{a} \mathrm{CE}$ ), "normas básicas" (art. 149.1.27. ${ }^{a} \mathrm{CE}$ ), “legislación básica” (art. 149.1.17. ${ }^{\mathrm{a}}$ y 18. ${ }^{\mathrm{a}} \mathrm{CE}$ ), en cuanto versiones semánticas de «lo básico", incorporan la acepción de fundamento o apoyo principal de algo, con vocación por la esencia, cuya finalidad consiste en asegurar, en aras de intereses generales superiores a los de las Comunidades Autónomas, un común denominador normativo" (STC 48/1981).

20 BVerfGE 7, 377 (404, 414).

21 BVerfGE 25, 1 (16) 
en transitoriamente viable dotándole de alguna estabilidad, en parte mediante el tratamiento homogéneo de las diferentes listas de competencias. Siendo entretanto alta la descentralización política y administrativa, no cabe hablar, sin embargo, sea de una consolidación del régimen territorial, sea de un previsible fin de las tensiones. De ahí el grado considerable de conflictos de competencia que las Comunidades Autónomas llevan al Tribunal Constitucional. Ahora bien, nuestros Magistrados caen a veces en la trampa de la voracidad competencial de ciertas Comunidades Autónomas, - el género fosilizado de glosa forense en el que parte de la jurisprudencia se ha ido extraviando mostrándose incapaces de elevar los contenciosos a una teoría constitucional de los intereses generales. El Tribunal alemán nos indica, en cambio, el camino dogmático a seguir tanto en la racionalización de los conflictos de competencia como a la hora de moderar la autonomía privada mediante su limitación por los intereses generales.

\section{DE DERECHOS SUBJETIVOS A GARANTÍAS INSTITUCIONALES. PRESUPUESTOS CONSTITUCIONALES PARA LA DETERMINACIÓN MATERIAL DE LOS INTERESES GENERALES}

Bajo nuestra Constitución, a los efectos de determinar los intereses generales, el postulado de Estado de Derecho no se ciñe a meros aspectos de la limitación del poder y de la distribución de competencias. A tal postulado pertenecen también elementos de justicia social y la calidad de vida (Preámbulo) como presupuestos materiales. Hay que ir, pues, a una concreción material de la idea constitucional de los intereses generales. En nombre de los mismos, el Tribunal Constitucional ha ido, así, al paso del tiempo tallando también uno tras otro bienes públicos ${ }^{22}$, limitadores de los derechos fundamentales. La jurisprudencia ha interpretado los intereses generales, según el caso, en términos de a) derechos fundamentales en cuanto normas de un orden objetivo de valores; b) reducción de la propiedad privada y la libertad empresarial a garantías institucionales; c) principios rectores de la política social y económica como parámetros de cierre de los fundamentos materiales de los intereses generales. Tal jurisprudencia anda solícita de un empeño dogmático que hilvane una teoría constitucional de los intereses generales como suma de las reservas a la autonomía privada, que comprende pero no se agota en el programa normativo de los arts. 103 y 128 CE. De esto se trata aquí.

Veamos.

a) En primer lugar, los derechos en su vertiente objetiva en cuanto principios del orden jurídico ${ }^{23}$.

22 Vid. Michael Anderheiden, Gemeinwohlförderung durch die Bereitstellung kollektiver Güter, op. cit.

23 La jurisprudencia constitucional ha declarado que los derechos fundamentales tienen junto a su calidad de derechos subjetivos asimismo una función y consiguiente vertiente institucional (STC 25/1981). A la postre, no son los derechos y libertades como pretensiones subjetivas un fin 
El principio de igualdad formal exige a los poderes públicos que a iguales supuestos de hecho se apliquen iguales consecuencias jurídicas ${ }^{24}$. La libertad de empresa, la libertad de circulación de bienes, de capitales, de servicios y de mano de obra y la unidad del orden económico han de ser compatibles con la igualdad de todos los españoles en el ejercicio de los derechos y en el cumplimiento de los deberes constitucionales en cualquier parte del territorio ${ }^{25}$.

en sí mismos; su ejercicio ha de venir orientado, antes bien, a realzar la institución garantizada. En la estela de Häberle, Cruz Villalón opta por identificar la cláusula del contenido esencial de los derechos fundamentales con la noción de garantía institucional. Ciertamente, no todo son garantías institucionales; ni siquiera lo son todos los Principios rectores, como pretende Alonso García. Más en todo caso, lo que queda en pié es la crítica de Häberle a la contraposición schmittiana entre la noción de institución y una libertad ilimitada previa al Estado y al Derecho, así como frente al empeño de García de Enterría, de reducir a derechos subjetivos todo el entramado objetivo del Derecho. La institucionalización de los derechos fundamentales (cfr. Peter Häberle, Die Wesensgehaltsgarantie des Art. 19. Abs. 2 Grundgesetz. Zugleich ein Beitrag zum institutionellen Verständnis der Grundrechte und zur Lebre vom Gesetzesvorbehalt 3. erweiterte Auflage, Heidelberg: C. F. Müller Juristischer Verlag, 1983) es la perspectiva correcta desde la que reequilibrar una cierta dogmática elaborada hasta el momento.

La función y consiguiente vertiente institucional de los derechos como elementos esenciales de un ordenamiento objetivo de la comunidad nacional (STC 25/1981) completa el círculo de limitaciones a la autonomía privada a favor de los intereses generales. Desde tal perspectiva derechos subjetivos como propiedad, libertad empresarial, trabajo, libertad profesional, libertad sindical y libre expresión se traducen en los institutos de economía de mercado, relaciones laborales y foro público. En tal condición, tienen una función pública (STC 64/1988), cobran naturaleza y están sometidos a un estatuto públicos. Así, por ejemplo, en cuanto la economía de mercado es la versión institucional de propiedad privada y libertad empresarial, comprende el haz de funciones sociales y consiguientes límites de aquéllas. La productividad (art. 38 CE) —de mercancías, riqueza, servicios-, la creación de empleo y la distribución del producto nacional bruto (Preuss, 1969) son las funciones institucionales de la economía de mercado. De ahí su relevancia constitucional. La propiedad privada y la libertad empresarial no albergan ya expectativas subjetivas que sean fines en sí mismos.El ejercicio de la propiedad privada y la libertad empresarial habrá de dirigirse a la realización de la productividad, la creación de empleo y una distribución del producto nacional bruto no disconforme con la Constitución. La propiedad privada y la libertad empresarial se han convertido en normas de competencia, de habilitación por el Estado para satisfacer específicas funciones institucionales. La libertad empresarial deja de ser un mero derecho para configurarse como facultad en la que predomina el carácter de garantía institucional (STC 83/1984). Propiedad privada y libertad empresarial únicamente se legitiman en la medida en que sirvan a su función constitucional, a los efectos que con su ejercicio se pretende alcanzar. Cfr.: Peter Häberle, Die Wesensgehaltsgarantie des Art. 19. Abs. 2 Grundgesetz. Zugleich ein Beitrag zum institutionellen Verständnis der Grundrechte und zur Lehre vom Gesetzesvorbehalt 3. erweiterte Auflage, Heidelberg: C. F. Müller Juristischer Verlag, 1983; Olivaer Lepsius, Besitz und Sachherrschaft im Öffentlichen Recht., Tübingen: Mohr Siebeck Verlag, 2002

$24 \mathrm{El}$ principio de igualdad (art. $14 \mathrm{CE}$ ) ha sido configurado como un derecho de los ciudadanos a recibir un trato no-discriminatorio. Obliga y limita a los poderes públicos a respetarlo y exige que a iguales supuestos de hecho se apliquen iguales consecuencias jurídicas. Veda, por tanto, el recurso a elementos arbitrarios o carentes de justificación para introducir diferencias (STC 27/2004). vid. Konrad Hesse, Der allgemeine Gleichsheitssatz in der neueren Rechtsprechung des Bundesverfassungsgerichts zur Rechtsetzungsgleichbeit, in Wege und Verfahren des Verfassungslebens Festschrift für Peter Lerche zum 65, Geburtstag, P. Badura und R. Scholz Hrs., München: C. H. Beck, 1993

25 La Constitución económica es el conjunto de normas destinadas a proporcionar el marco jurídico fundamental para la estructura y funcionamiento de la actividad económica, resaltando la 
En su vertiente objetiva como principio del orden jurídico, la igualdad se extiende al derecho al trabajo y a las relaciones laborales. El modelo de relaciones laborales comprende la garantía institucional de los sindicatos y las asociaciones empresariales, la libertad sindical, el derecho de negociación colectiva y el principio de igualdad. Merced a la tutela de las relaciones laborales, España se articula como Estado social de Derecho: tal postulado ha supuesto para el Tribunal Constitucional un potente instrumento de interpretación y aplicación en el ámbito laboral de la normativa constitucional ${ }^{26}$.

importancia que adquiere la exigencia de que los principios básicos del orden económico sean unos y los mismos en todo el ámbito nacional, como proyección concreta del más general principio de unidad que el art. 2 CE consagra (SSTC 1/1982; 11/1984; 29/1986; 64/1990).

De la Constitución se deriva la unicidad del orden económico nacional, que trae como consecuencia la existencia de un mercado único (STC 87/1985). Esta unidad de mercado supone la libertad de circulación sin trabas por todo el territorio nacional de bienes, capitales, servicios y mano de obra (art. 139.2 CE) y la igualdad de las condiciones básicas de ejercicio de la actividad económica (arts. 139.1; 149.1.1. ${ }^{a}$ CE) (SSTC 96/1984; 29/1986; 88/1986).

La unicidad del orden económico nacional requiere la existencia de un mercado único y que la unidad de mercado descanse sobre la libre circulación de bienes y personas por todo el territorio español (art. 139.2 CE) y la igualdad de las condiciones básicas de ejercicio de la actividad económica (arts. 139.1; 149.1 CE), sin los cuáles no es posible alcanzar en el mercado nacional el grado de integración que su carácter unitario impone (STC 64/1990).

La exigencia de que los principios básicos del orden económico sean unos y los mismos en todo el ámbito nacional es una proyección concreta del más general principio de unidad que el art. 2 CE consagra (SSTC 1/1982; 11/1984; 24/1986). De esa unidad se infiere como consecuencia necesaria la exigencia de un mercado único (STC 88/1986), configurándola como un límite de las competencias autonómicas (STC 71/1982) derivado implícitamente del art. 139.2 CE (SSTC 1/1982; 86/1984; 87/1985).La libertad de empresa, la libertad de circulación de bienes, capitales, servicios y mano de obra (art. 139; 149.1.1. ${ }^{a}$ CE) (SSTC 37/1981; 1/1982; 71/1982; 32/1983; 88/1986) y la unidad del orden económico (STC 133/1997) han de ser compatibles con la igualdad de todos los españoles en el ejercicio de los derechos y en el cumplimiento de los deberes constitucionales en cualquier parte del territorio (art. 139.1 en conexión con arts. 14, 30-53, 1381. y 2. y 149.1.1. ${ }^{\mathrm{a}}$ CE) (STC 37/1981).

26 El modelo de relaciones laborales comprende la garantía institucional de los sindicatos y las asociaciones empresariales (art. $7 \mathrm{CE}$ ), la libertad sindical (arts. 28 y 7 en conexión con el art. $37.1 \mathrm{CE}$ ), el derecho de negociación colectiva (art. 37.1, en conexión con los arts. 7, 14.1, 38 y 139.1 CE) y el principio de igualdad (art. 14 en relación con art. 9.2 CE). Merced a la tutela de las relaciones laborales, España se articula como Estado social de Derecho (art. 1.1 CE): tal postulado ha supuesto para el Tribunal Constitucional un poderoso instrumento de interpretación y aplicación en el ámbito laboral de la normativa constitucional (SSTC 11/1981; 19/1982; 3/1983; 14/1983; 6/1984; 18/1984; 83/1984; 88/1985; 39/1986).

$\mathrm{Ni}$ las organizaciones empresariales forman mundos separados y estancos respecto del resto de la sociedad, ni la libertad de empresa (art. $38 \mathrm{CE}$ ) legitima el que quiénes prestan servicios en aquéllas por cuenta y bajo la dependencia de sus titulares deban soportar despojos transitorios o limitaciones injustificadas de sus derechos fundamentales y libertades públicas: las manifestaciones de "feudalismo industrial" repugnan al Estado social y democrático de Derecho y a los valores superiores de libertad, justicia e igualdad a través de los cuáles ese Estado toma forma y se realiza (art. 1.1 CE) (STC 88/1985). El art. $40.2 \mathrm{CE}$ exige en el campo laboral diferenciar el régimen jurídico del trabajador respecto del empresario que compense la desigualdad económica de partida... puesto que la diferencia de régimen jurídico entre trabajador y empresario aparece exigida por el propio principio de igualdad material (art. 9.2 CE) y constituye instrumento ineludible para su debida efectividad, compensando una desigualdad económica de partida (SSTC 8/1983; 210/1990). 
La autonomía de la voluntad del empresario va a verse así condicionada por la dimensión colectiva de la relación de trabajo, que se traduce en la negociación colectiva, a la que el Tribunal Constitucional reconoce una relevancia cuasi-pública. En relación con el cierre empresarial, el Tribunal Constitucional ha rechazado la doctrina alemana de la paridad de armas, destacando el muy distinto tratamiento constitucional del derecho de huelga y del cierre patronal. Al declarar el reconocimiento de una desigualdad originaria, referencia obligada en la aplicación del valor de la igualdad en el ámbito laboral, nuestro más alto intérprete de la Constitución hace una excelente figura frente al Bundesverfassungsgericht.

En la concepción del Tribunal Constitucional, el art. 9.2 CE compromete la acción de los poderes públicos, a fin de que pueda alcanzarse la igualdad sustancial entre los individuos con independencia de su situación social. La igualdad material o real y efectiva es una finalidad propia del Estado social de Derecho.... De ahí que, en definitiva, más allá de que las manifestaciones de "feudalismo industrial" repugnen al Estado de Derecho, la finalidad compensadora del Derecho laboral en garantía de la promoción de una igualdad real exige un minimo de desigualdad formal en beneficio de los trabajadores.

Precisamente como medio de potenciar un cierto equilibrio, tal transformación del derecho de contratos va a limitar la libertad en el ámbito de la relación de trabajo. Sin perjuicio de las garantías de la propiedad y la libertad de empresa, se va a limitar, por medio de una intensa intervención estatal y del reconocimiento de la negociación colectiva, la autonomía de la voluntad - tanto del empresario como del trabajador- . Ley y convenio colectivo van a tener como misión configurar espacios de igualdad en una relación estructuralmente desigual. En ese contexto, la garantía del derecho al trabajo como derecho a estabilidad en el empleo salvo despido por causa justa y la tutela de la profesionalidad tienen una virtualidad instituyente de la sociedad civil ${ }^{27}$.

Con el principio de justicia fiscal, se extiende a la redistribución de la renta el principio de igualdad material, que acabo de exponer.

La libertad de comunicación nos ofrece asimismo un ejemplo significativo de la vertiente objetiva de los derechos. La Constitución protege el derecho a expresarse libremente mediante la palabra, el escrito o cualquier otro medio de reproducción y el derecho a comunicar o recibir libremente información veraz por cualquier medio de difusión. El derecho a difundir las ideas y opiniones comprende en principio el derecho de crear los medios materiales a través de los cuáles la difusión se hace posible. Ciertamente, junto a las libertades de expresión e información por cualquier medio de difusión, la Constitución consagra el derecho de crear los medios de comunicación indispensables para el ejercicio de estas libertades. Por más que este derecho a

27 El principio de justicia fiscal extiende a la redistribución de la renta (art. $31 \mathrm{CE}$ ) la subordinación de la riqueza a los intereses generales (art. 128.1 CE), el principio de solidaridad (arts. 2 y 138.1 CE) y el principio de igualdad material (art. 9.2 CE) (SSTC 19/1989; 53/1993; 54/1993; 159/1997; 183/1997; 55/1998). 
crear soportes o instrumentos de comunicación presente indudables límites. Entre ellos, el Tribunal considera conforme a la Constitución la reserva como servicio público de la titularidad estatal de la televisión (art. $128 \mathrm{CE}$ ).

Los derechos de libre expresión y de información, en su dimensión de derechos de libertad, significan básicamente ausencia de interferencias o intromisiones ilegítimas en el proceso de comunicación; pero, en su dimensión institucional, suponen, a la vez, la garantía de una opinión pública libre y del mantenimiento de un pluralismo político. En definitiva, el art. $20 \mathrm{CE}$ asegura una comunicación pública libre sin la cual vendría falseada la libertad democrática $^{28}$.

b) En segundo lugar, las reservas a la propiedad privada y la libertad empresarial en nombre del interés general. La subordinación de la riqueza al interés general como postulado refleja una de las tensiones fundamentales del Derecho de nuestra economía de mercado, que tal vez no ha recibido hasta ahora la atención que merece. La utilidad pública, la función social de la propiedad, la libre competencia, la ordenación del territorio y de la acción urbanística, el dominio público y las obras públicas de interés general como límites de la autonomía privada dotan a la propiedad de un estatuto público que reduce su protección a la de una mera garantía institucional.

- b1) La Constitución reconoce un derecho a la propiedad privada como haz de facultades individuales sobre cosas; pero, al mismo tiempo, tal derecho conlleva una serie de obligaciones en atención a la finalidad o utilidad social que, en aras del interés general, cada bien objeto de dominio está

28 El derecho a comunicar o recibir libremente información veraz por cualquier medio de difusión y la naturaleza jurídica de la televisión como servicio público esencial de titularidad estatal (art. 20 CE) (SSTC /1981; 12/1982; 74/1982; 35/1983; 106/1986; 20/1990; 206/1990; 85/1992; 31/1994; 127/1994; 79/1999; 112/2006) El art. 128.2 CE permite a la Ley reservar al sector público "recursos" o "Servicios esenciales". La noción de "Servicios esenciales" puede abarcar estos servicios de radiodifusión, para suministrar información plural a través de determinados soportes técnicos y permitir formar opinión pública. La asunción por los poderes públicos de la actividad televisiva como servicio público no puede tener otra justificación que servir a los intereses generales y asegurar la eficacia de otros bienes y principios o derechos constitucionales. Se trata no sólo de asegurar sin interrupciones el cumplimiento de ciertas actividades que satisfacen una necesidad esencial, la obtención de una información libre y plural por los ciudadanos por medio de la televisión, sino también de permitir el acceso en condiciones de igualdad al ejercicio de los derechos fundamentales a suministrar información y pensamiento libre a través de este soporte técnico.

La distinción entre los derechos fundamentales garantizados por el art. 20.1 CE y los derechos a instaurar soportes, instrumentos o medios de comunicación indispensables para el ejercicio de estas libertades es jurisprudencia consolidada del Tribunal Constitucional: la Constitución consagra, junto a las libertades de expresión e información por cualquier medio de difusión, el derecho de crear los medios de comunicación indispensables para el ejercicio de estas libertades. En la línea de las SSTC 12/1982; 74/1982; 35/1983; 106/1986; 206/1990; 119/1991; 31/1994, la declaración de la televisión como servicio público no es contraria a la Constitución.

Por lo demás, la libertad de empresa no resulta constitucionalmente resquebrajada por limitaciones derivadas de las reglas que disciplinen proporcionada y razonablemente el mercado (SSTC 37/1981; 88/1985; 37/1987; 17/1990), y, entre otras, por el sometimiento a una autorización administrativa que tutele distintos bienes constitucionales y los derechos de otros (SSTC 227/1993; 127/1994). 
llamado a cumplir. La profunda transformación experimentada por la propiedad en el último siglo como derecho individual y en cuanto institución se manifiesta, así, en diversos tipos de propiedades dotados de estatutos jurídicos varios e impide considerarla por más tiempo como la figura definida en el Código Civil (caso RUMASA; caso Ley del Parlamento de Andalucía de Reforma Agraria).

Corresponde al legislador delimitar el contenido del derecho de propiedad en relación con cada tipo de bienes. Las cláusulas de la función social, la utilidad pública y el interés social permiten, así, la intervención legislativa en el destino económico de la propiedad y de la empresa, sin perjuicio del respeto a su contenido esencial. El Tribunal Constitucional hace depender la validez de la expropiación de la utilidad pública o del interés social. Dado que la expropiación comporta una severa intervención en el derecho de propiedad, habrá de justificarse rigurosamente y, en el marco de la ponderación, habrá así que tener especialmente en cuenta el alto rango que la Constitución reconoce a la propiedad privada: en su caso, la expropiación deberá responder a un interés público importante y urgente.

El límite para el legislador se encontrará en no sobrepasar la barrera más allá de la cual las facultades de disponibilidad que supone el derecho dominical no resulten recognoscibles en la posibilidad efectiva de realizar el derecho en cada momento histórico. Por otra parte, la reserva al derecho de propiedad del art. $33.3 \mathrm{CE}$ tiene el valor de una determinación negativa de competencia: presupuestos constitucional — materiales limitan la facultad del Estado de expropiar. Ciertamente, de la Constitución no se deja inferir qué fines en concreto justifican la expropiación. Sí excluye, en cambio, para una expropiación determinados fines: así, la gravación fiscal nunca tendrá alcance confiscatorio.

El art. 132.2 CE, al tiempo que excluye directamente la titularidad privada de algunos bienes, permite al legislador declarar la demanialidad de otros la opción de incluir las aguas continentales y la costa en el dominio público, sin ir más lejos. Al encomendar al legislador una configuración legal de los derechos patrimoniales, deberá aquél tomar en consideración el interés general y la dimensión social inherentes al carácter público de los bienes sobre los que recaiga la declaración de demanialidad ${ }^{29}$.

29 Cfr.: SSTC 111/1983 caso RUMASA; 37/1987 caso Reforma Agraria de Andalucia; 89/1994; 112/2006, SSTC 37/1987; 170/1989; 204/2004).

En relación con cada tipo de bienes, corresponde al legislador delimitar el contenido del derecho de propiedad. Las cláusulas de la función social, la utilidad pública y el interés social (art. 33 CE) permiten, así, la intervención legislativa en el destino económico de la propiedad y de la empresa (SSTC 111/1983; 37/1987), sin perjuicio del respeto a su contenido esencial (art. 53.1 CE) (SSTC 11/1981; 37/1987). Partiendo de las previsiones de los arts. 128.1, 40, 45 y $130 \mathrm{CE}$, los poderes públicos deben "delimitar el contenido del derecho de propiedad en relación con cada tipo de bienes". Esto no supone una absoluta libertad del legislador para "anular la utilidad meramente individual del derecho". El límite se encontrará, a efectos del art. $33.3 \mathrm{CE}$, en no sobrepasar la barrera más allá de la cuál las facultades de disponibilidad que supone el derecho dominical no resulten recognoscibles en la posibilidad efectiva de realizar el derecho en cada momento histórico (SSTC 
- b2) Libertad empresarial y un mercado de libre competencia definido como interés público.

La libertad empresarial entraña el reconocimiento a los particulares de la libertad de decisión para crear empresas y dirigir su actividad, así como las consiguientes libertades de contratación, de organización y de inversión. El respeto a la libertad empresarial marca "los límites dentro de los que han de moverse los poderes constituídos".

En nombre del interés general, la jurisprudencia ha ido configurando al paso del tiempo una serie de límites a la libertad empresarial: de los principios básicos del orden económico, medidas de política económica de alcance nacional al servicio de objetivos fijados por la Constitución y el mercado único a la libertad de circulación de bienes, capitales, servicios y mano de obra sin trabas por todo el territorio nacional y la igualdad de las condiciones básicas de ejercicio de la actividad económica; de la unidad del mercado de valores, de la ordenación del crédito, de la banca y de los seguros, del sistema monetario y de la política financiera a la igualdad en el acceso a toda suerte de mercados ${ }^{30}$.

11/1981; 37/1987; 170/1989)... Al establecer con carácter general una nueva configuración legal de los derechos patrimoniales, el legislador debe tener en cuenta las exigencias del interés general... y debe tomar en consideración el interés general y la dimensión social inherentes al carácter público del bien sobre el que recáen (STC 227/1988 CE). Conforme al art. $33.3 \mathrm{CE}$, Nadie podrá ser privado de sus bienes y derechos sino por causa justificada de utilidad pública o interés social, mediante la correspondiente indemnización y de conformidad con lo dispuesto por las leyes. El Tribunal Constitucional hace depender la validez de la expropiación del fin público, a saber, la utilidad pública o el interés social. De ahí que el legislador deba precisar los presupuestos y el fin de la expropiación. Dado que la expropiación comporta una severa intervención en el derecho de propiedad, habrá rigurosamente de justificarse y en el marco de la ponderación habrá, así, que tener especialmente en cuenta el alto rango que la Constitución reconoce a la propiedad privada: en su caso, la expropiación deberá responder a un interés público importante y urgente (STC 227/1988 CE).

$30 \mathrm{Al}$ reconocer el art. $38 \mathrm{CE}$ la libre empresa en el marco de la economía de mercado, establece los parámetros del orden económico. Ahora bien, las modificaciones de la concreta libertad de los empresarios se ubican no en el marco del art. $38 \mathrm{CE}$ sino en los campos especiales a los que se refiera cada tipo de actividad.

El art. $38 \mathrm{CE}$ se entiende como libertad de actuación, de elección por la empresa de su propio mercado, cuyo ejercicio en condiciones básicas de igualdad queda constitucionalmente garantizado, y cuyo respeto marca "los límites dentro de los que necesariamente han de moverse los poderes constituidos al adoptar medidas que incidan sobre el sistema económico de nuestra sociedad ( SSTC 37/1981; 71/1982; 80/1983; 96/1984; 88/1986; 64/1990; 264/1993; 118/1996; 208/1999; 124/2003). El mantenimiento de estos límites está asegurado por una doble garantía, la de la reserva de ley y la que resulta de la atribución a cada derecho o libertad de un núcleo del que ni siquiera el legislador puede disponer, de un contenido esencial (art. 53.1 CE).

Sólo puede hablarse de un contenido esencial de la libertad de empresa para aludir a un contenido más allá del cual se adopta un sistema económico que ya no se ajusta a los parámetros constitucionalizados. Mientras el orden económico se desenvuelva dentro de los principios de libre empresa y economía de mercado no es preciso que sean libres todas las actuaciones de las empresas y de los empresarios; de ahí que las medidas de coerción tendentes a favorecer la libre empresa o la economía de mercado, por más que puedan limitar en concreto la libertad de los empresarios, no alteran los términos del art. 38 CE (voto particular de Díez-Picazo, STC 37/1981)

Garantizada la libertad de empresa, la Constitución va desgranando una serie de límites: por ejemplo, la libre circulación de personas y bienes en todos el territorio español (art. 139.2 CE) (STC 37/1981). 
Como pieza esencial del principio de unidad del orden económico y del sistema financiero nacional (SSTC 96/1984; 133/1997), también el mercado de valores limita la libertad empresarial. El mercado de valores comprende la colocación y la financiación a largo plazo así como las instituciones que efectúan estas operaciones. El principio de unidad de mercado comporta la interrelación de mercado de valores, sistema crediticio, sistema monetario y política financiera; los mismos se condicionan entre sí y condicionan a su vez la política económica del Estado, todo ello, además, en el marco de la libre circulación de capitales que rige en la Unión Europea (STC 133/1997).

La ordenación del crédito ha sido enmarcada en los principios básicos del orden económico resultantes de la Constitución económica y, especialmente, en la exigencia de la unidad del orden económico en todo el ámbito del Estado. Una de las manifestaciones de dicha unidad es el principio de unidad del mercado - y, por tanto, del mercado de capitales-, reconocido por el art. 139.2 CE al disponer, que ninguna autoridad podrá adoptar medidas que directa o indirectamente obstaculicen la libre circulación de bienes en todo el territorio español. Compete al Estado configurar los tipos de mercados oficiales y no - oficiales en los que haya de tener lugar la negociación de los valores y determinar las condiciones generales de los contratos propios de tales mercados - intermediarios bursátiles; sociedades y Agencias de valores. La Comisión Nacional del Mercado de Valores tiene como fin garantizar la unidad del mercado de valores. Los principios de unidad de mercado y las bases de la ordenación del crédito exigen homogeneidad de la regulación de efectos nacionales.

Según el Tribunal Constitucional, procede establecer un sistema de información que garantice la transparencia informativa del mercado de valores, dentro de una política económica tendente a liberalizar nuestro sistema financiero, potenciando el funcionamiento de los mecanismos del mercado dentro del mismo (SSTC 1/1982; 96/1984; 49/1988; 135/1992; 155/1993; 96/1996; 133/1997).

Otra manifestación de esa unidad del orden económico es la exigencia de adoptar medidas de política económica aplicables, con carácter general, a todo el territorio nacional, al servicio de objetivos de carácter económico fijados por la propia Constitución (arts. 40.1; 130.1; 131.1; 138.1 CE) (SSTC 96/1984; 37/1981; 1/1982; 64/1990). Según el Tribunal, cuando por la necesidad de asegurar un tratamiento uniforme de determinados problemas económicos o por la estrecha interdependencia de las actuaciones a realizar en distintas partes del territorio nacional, para conseguir objetivos de política económica nacional se precise una acción unitaria en el conjunto del territorio del Estado, éste podrá efectuar una planificación de detalle, siempre que la necesaria coherencia de la política económica general exija decisiones unitarias y no pueda articularse sin riesgo para la unidad económica del Estado a través de la fijación de bases y de medidas de coordinación (SSTC 29/1986; 133/1997).

Las competencias estatales del art. 149.1.11. ${ }^{a}$ CE son así instrumentos al servicio de una política monetaria y crediticia única y, por tanto, de una política económica común (STC 133/1997). Desde las SSTC 1/1982; 96/1984; 48/1988; 49/1988; 86/1989; 135/1992; 178/1992; 87/1993; 37/1997). Corresponde a la Comisión Nacional del Mercado de Valores velar por la transparencia de los diversos mercados, la correcta formación de los precios en los mismos y la protección de los inversores (STC 133/1997). La atribución de tales funciones a la Comisión Nacional del Mercado de Valores forma parte del ejercicio legítimo de las competencias del Estado, por cuanto constituye un presupuesto necesario para garantizar la unidad del mercado de valores que es una manifestación del principio de unidad del orden económico (SSTC 96/1984; 133/1997). Se trata de establecer un sistema de información que garantice la transparencia en el mercado de valores, dentro de una política económica tendente a liberalizar nuestro sistema financiero, potenciando el funcionamiento de los mecanismos de mercado dentro del mismo (STC 133/1997). La Comisión Nacional del Mercado de Valores localiza las decisiones en un centro unitario y garantiza, así, la unidad del mercado y la igualdad en el acceso al mismo (STC 133/1997). También los ferrocarriles y transportes terrestres, en cuanto obras públicas de interés general (art. 149.1.21. ${ }^{\mathrm{a}} \mathrm{CE}$ ), son interpretables como límites a la libertad empresarial. Actividades públicas relativas a la ordenación de las condiciones en las que se presta el servicio de traslado o desplazamiento de personas o mercancías (SSTC 203/1992; 118/1996): establecimiento y mantenimiento de un sistema común de transporte en todo el Estado, mediante la coordinación e interconexión de las redes, servicios o actividades que lo integran y de las acciones de los distintos órganos y Administraciones Públicas competentes. Satisfacción de las necesidades de la comunidad con el máximo grado de eficacia y 
Los preceptos constitucionales sobre propiedad privada, libertad empresarial, derecho al trabajo y libertad profesional y libertad sindical limitan materialmente la discrecionalidad del legislador y ponen riendas al activismo de los tribunales. Por otra parte, la primacía del interés general contrarresta, en fin, el subjetivismo de propietarios y empresarios respecto de los propios derechos.

El recorrido del texto y de la jurisprudencia revela la metamorfosis del derecho de propiedad privada y de la libertad empresarial, de derechos subjetivos en, a la postre, meras garantías institucionales. Estas responden a una técnica de protección, frente al legislador y los restantes poderes públicos, a favor de aquellos institutos que desempeñan un papel estructurador básico en el desarrollo del orden constitucional. El legislador no puede limitar los institutos jurídicos garantizados hasta el extremo de vaciarlos materialmente, hacerles perder su capacidad de despliegue y condenarlos a una existencia ficticia. Pero los asalariados no deberían echar prematuramente las campanas al vuelo: la propiedad y la libertad empresarial cuentan con el apoyo constitucional; en el bien entendido, eso sí, de que los derechos subjetivos no sirven al interés de privados sino al instituto mismo. La garantía institucional y los derechos subjetivos son compatibles y pueden darse simultáneamente - si bien, a efectos de interpretación, la perspectiva institucional y no el interés subjetivo es lo decisivo; la garantía de derechos subjetivos está subordinada y debe servir a la garantía institucional (Schmitt) ${ }^{31}$. Del despegue de la revolución industrial a la crisis económica de 1929 y el acceso legal al poder de los fascismos, el legislador gozó en la doctrina y entre los notables de gran aprecio. Ahora bien, tan pronto quebró tal confianza, las garantías institucionales

con el mínimo coste social. Mantenimiento de la unidad de mercado en todo el territorio español (art. 139.2 CE). Los poderes públicos promoverán la satisfacción de las necesidades de transporte de los ciudadanos en el conjunto del territorio español en condiciones idóneas de seguridad, con atención especial a las categorías sociales desfavorecidas y a las personas con capacidad reducida, así como a las zonas y núcleos de población alejados o de difícil acceso. En el marco del principio de la unidad de mercado, los Poderes Públicos buscarán la armonización de las condiciones de competencia entre los diferentes modos y empresas de transporte, tenderán a evitar situaciones de competencia desleal, y protegerán el derecho de libre elección del usuario y la libertad de gestión empresarial que únicamente podrán ser limitadas por razones inherentes a la necesidad de promover el máximo aprovechamiento de los recursos y la eficaz prestación de los servicios (STC 118/1996).

31 vid. Carl Schmitt, Freiheitsrechte und institutionelle Garantien der Reichsverfassung (1931), in: ders., Verfassungsrechtliche Aufsätze, Berlin: Duncker \& Humblot, 1928. Sobre un desarrollo más extenso del tema y para información bibliográfica, vid. A. López Pina, Comentario introductorio al Capítulo III del Título I, en Comentarios a la Constitución Española de 1978, Tomo IV, edición de Oscar Alzaga, Madrid: Cortes Generales; Editoriales de Derecho Reunidas, 1997. Cfr. asimismo Konrad Hesse, Significado de los derechos fundamentales, en Manual de Derecho constitucional, Benda, Maihofer, Vogel Hesse, Heyde; edición, prolegomena y traducción de A. López Pina; Prólogo a la segunda edición de M. A. García Herrera, Madrid: Marcial Pons Ediciones Jurídicas, 1996; Luciano Parejo, Estado social y Administración pública, Madrid: Ed. Civitas, 1983; id., Garantía institucional y autonomías locales, Madrid: Instituto de Estudios de Administración Local, 1981; Juan Alfonso Santamaría Pastor, Fundamentos de Derecho administrativo, Madrid: Editorial Centro de Estudios Ramón Areces, 1988 
cobraron el valor de definir constitucionalmente al legislador dónde radica el limite de los limites de su competencia y discrecionalidad.

En la jurisprudencia llama la atención que el principio de libre competencia, del que se hace especialmente devoto el Tribunal (caso Ley de Defensa de la Competencia), devenga, a raíz de la incorporación de España a la Comunidad Europea, por primera vez, una cuestión de relevancia constitucional. Empero, en los Estados occidentales el principio de libre competencia no pertenece a las columnas de la arquitectura constitucional. Todo lo más, es inferible de derechos fundamentales como la libertad empresarial y la libertad de profesión y de trabajo en conexión con el principio de igualdad: nuestro Tribunal da la impresión de haber olvidado que, como dice Christian Tomuschat, el bien de la sociedad se basa en un acervo de valores en el que la libertad, el derecho de autodeterminación y los derechos sociales ocupan el primer lu$\operatorname{gar}^{32}$. No deja, así, de ser significativa la reciente apuesta de nuestro Tribunal por la blairista igualdad de oportunidades para competir en el mercado ${ }^{33}$, y que por el camino haya ido perdiendo la idea material de igualdad, que bajo los mandatos de García Pelayo y Tomás y Valiente inspirara su jurisprudencia.

c) En tercer lugar, los principios rectores de la Política social y económica. La propiedad privada y la libertad empresarial habrán de ser ponderadas, asimismo, con otros bienes públicos con los que pueden entrar en colisión.

La seguridad, la salud y los intereses económicos del consumidor ${ }^{34}$ aparecen en la Constitución como un principio rector de la política social y económica, cuya garantía impone a los poderes públicos limitar la libertad empresarial. La Administración tutela los intereses colectivos de los consumidores al servicio de una transparencia en los precios y de una defensa en la calidad de los bienes y servicios. La reglamentación de los productos alimenticios y farmacéuticos es definida como premisa del sistema de protección de la salud.

32 Bajo la presidencia de Cruz Villalón, el Tribunal hace suya la ponencia del Magistrado ponente Vives Antón para declarar la defensa de la competencia un elemento definitorio del mercado (STC 208/1999). Para una visión constitucional relativizadora de la libre competencia, vid. Christian Tomuschat, Daseinsvorsorge und Wettbewerbsprinzip in der Europäischen Union in: Die Rolle der europäischen Institutionen in der Wirtschaftspolitik, Horst Tomann Hrsg., Baden-Baden: Nomos Verlagsgesellschaft, 2006.

33 Sobre la diferencia entre la igual libertad de nuestra Constitución como postulado y la blairista igualdad de oportunidades para competir vid. A. López Pina, La Constitución territorial de España. El Orden jurídico en garantía de la igual libertad, Madrid: Marcial Pons Ediciones Jurídicas, 2006.

34 La protección de la seguridad, la salud y los intereses económicos del consumidor (art. 51; 149.1.8. ${ }^{\circ}$; $149.1 .16 .{ }^{a}$ CE) es un fin de la ordenación estatal del mercado (SSTC 71/1982; 88/1986; 15/1989). La reglamentación de productos alimenticios es capital en la protección de la salud en materia alimentaria-legislación sobre productos farmacéuticos (art. 149.1.16. ${ }^{\text {a }} \mathrm{CE}$ ); intervención pública orientada a la tutela de intereses colectivos de los consumidores, al servicio de una transparencia en los precios y una defensa en la calidad de los bienes y servicios (STC 71/1982). En la defensa estatal de los consumidores éstos aparecen como destinatarios de unos productos ofrecidos por las empresas, productos cuyas condiciones de oferta se pretende regular protegiendo la seguridad, la salud y los legítimos intereses económicos de los consumidores (art. 51. CE) (STC 88/1986). 
De la defensa de los consumidores la jurisprudencia transita a la protección de los inversores ${ }^{35}$ : el Estado se propone garantizar la transparencia en las transacciones financieras, la correcta formación de los precios y la protección de los inversores, la solvencia de las entidades que actúan en el mercado de valores y la igualdad en el comercio de valores entre los operadores del mercado y, en última instancia, la estabilidad del sistema financiero.

El Tribunal Constitucional es especialmente rotundo al imponer a los poderes públicos el deber de cohonestar el desarrollo económico con la protección del medio ambiente, el paisaje incluido, en términos de un desarrollo sostenible, para asegurar una mejor calidad de vida ${ }^{36}$. En el caso del medio ambiente, éste ha de ser defendido de las propias acciones del hombre, en beneficio de los demás y de las generaciones sucesivas.

En consecuencia, la ordenación del territorio, de la utilización del suelo y de la acción urbanística de acuerdo al interés general y la protección del dominio público hidráulico y marítimo-terrestre del Estado, tienen la preservación del medio ambiente, el paisaje incluido, como referencia normativa. De ahí su virtualidad de límites a la propiedad privada y la libertad empresarial en cuanto a la gestión del suelo.

La enumeración hace evidente que, según el caso, se trata de bienes locales, regionales o mundiales. Los órganos estatales deberán perseguir el bien público de la preservación del medio ambiente según se tercie: el paisaje de lagos y montañas, la protección de plantas autóctonas o de especies del reino animal son bienes públicos, pero de alcance regional o nacional. Por el contrario, otros bienes colectivos como la preservación del equilibrio ecológico hay que plantearlos mundialmente; en consecuencia, España trata de hacerles justicia en el seno de la Unión Europea y por medio del Derecho internacional.

35 De la protección de los consumidores la jurisprudencia transita a la protección de los inversores. Con la Ley del Mercado de Valores, relativa a los principios de prioridad del cliente, de transparencia del mercado, del uso de información privilegiada y de la separación de funciones, el Estado quiere garantizar la transparencia en las transacciones financieras, la correcta formación de los precios y la protección de los inversores (STC 133/1997).

A efectos de situaciones en las que determinadas entidades que operan en el mercado de valores se encuentren en una situación de excepcional gravedad que ponga en peligro la efectividad de sus recursos propios o su estabilidad, liquidez o solvencia el Estado tiene facultades para intervenir al fin de la ordenación básica del crédito, más concretamente, al mantenimiento de la regularidad y seguridad de las entidades que conforman el mercado de valores (STC 133/1997). El Estado ha de garantizar la igualdad de los inversores en el acceso a unos mercados en los que la información es decisiva a la hora de realizar operaciones bursátiles (STC 133/1997). La Ley del Mercado de Valores quiere establecer una regulación uniforme al fin de garantizar la unidad del mercado, la solvencia de las entidades que actúan en el mercado de valores, la igualdad entre los operadores del mercado, la igualdad y la libertad en el comercio de valores y, en última instancia, la estabilidad del sistema financiero (STC 133/1997). Vid. asimismo nota a pié de página (30)

36 Una y otra vez ha subrayado el Tribunal Constitucional el deber de cohonestar el desarrollo económico con la protección del medio ambiente, el paisaje incluido, en términos de un desarrollo sostenible, para asegurar una mejor calidad de vida (SSTC 149/1991; 118/1996; 28/ 1997; 61/1997; 207/1999; 164/2001). 
Los principios rectores de la política social y económica cierran, así, el círculo de limitaciones a la autonomía privada en nombre de los intereses generales abierto por la vertiente institucional de los derechos como elementos esenciales de un ordenamiento objetivo de la comunidad nacional y las reservas a la propiedad privada y a la libertad empresarial en forma de estatuto público de las mismas.

Finalmente, como apostilla, una palabra, en particular, sobre la lengua castellana como lengua española oficial del Estado en cuanto condición material para el ejercicio de las libertades ${ }^{37}$. Breve atención merece la política lin-

$37 \mathrm{Al}$ ordenar la Constitución la "realidad plurilingüe de la Nación española" (STC 82/1986), que es asumida como un patrimonio cultural digno de especial respeto y protección (art. 3.3 CE), establece un régimen de cooficialidad lingüística del castellano "lengua española oficial del Estado (art. 3.1 CE), y de las "demás lenguas españolas", las cuales "serán también oficiales en las respectivas Comunidades Autónomas de acuerdo con sus Estatutos" (art. 3.2 CE). De suerte que en la organización territorial del Estado compuesto que han configurado la Constitución y los Estatutos de Autonomía existen unos "territorios dotados de un estatuto de cooficialidad lingüística" en los que el uso por los particulares, a su elección, de una de las dos lenguas oficiales «tiene efectivamente plena validez jurídica en las relaciones que mantengan con cualquier poder público radicado en dicho territorio" (STC 82/1986).

De este modo, y con independencia de la realidad y el peso social de cada una de ellas (STC 82/1986), el régimen de cooficialidad lingüística establecido por la Constitución y los Estatutos de Autonomía presupone no solo la coexistencia sino la convivencia de ambas lenguas cooficiales, para preservar el bilingüismo existente en aquellas Comunidades Autónomas que cuentan con una lengua propia y que constituye, por sí mismo, una parte del patrimonio cultural al que se refiere el art. 3.3 CE. Situación que necesariamente conlleva, de un lado, el mandato para todos los poderes públicos, estatal y autonómicos, de fomentar el conocimiento y asegurar la protección de ambas lenguas oficiales en el territorio de la Comunidad. De otro, que los poderes públicos deben garantizar, en sus respectivos ámbitos de competencia, el derecho de todos a no ser discriminado por el uso de una de las lenguas oficiales en la Comunidad Autónoma (Ley 7/1983 de Normalización Lingüística en Cataluña).

El art. 3 CE prevé un tratamiento diferenciado: respecto del castellano, establece para todos los españoles el deber de conocerlo y el derecho de usarlo; tal deber de conocer y usar no se declara, en cambio, para las lenguas autonómicas. En cualquier caso, la Constitución asegura un conocimiento efectivo que permita a ciudadanos y residentes dirigirse en una de las dos lenguas, a su elección, a todos los poderes públicos "con plena validez jurídica" y, de igual modo, comunicarse de forma directa con los demás en cualquier lugar del territorio nacional. Ello implica un régimen de convivencia entre las dos lenguas cooficiales, así como el mandato de fomentar el conocimiento y garantizar el mutuo respeto y la protección de ambas lenguas a todos los poderes públicos.

Los límites constitucionales que las Comunidades Autónomas bilingües deben respetar, vienen determinados por el modelo de cooficialidad lingüística en el que es esencial el principio de libertad de elección. A tenor del mismo, todo residente en una Comunidad Autónoma bilingüe tiene derecho a elegir, en sus relaciones con los poderes públicos y entre particulares, la lengua castellana como medio de expresión lingüística; lo cual excluye, que quepa imponérsele el uso del idioma autonómico.

Respecto del empleo del castellano como lengua docente, "corresponde al Estado velar por el respeto de los derechos lingüísticos en el sistema educativo y, en particular, «el derecho a recibir enseñanza en la lengua oficial del Estado". "El deber constitucional de conocer el castellano presupone la satisfacción del derecho de los ciudadanos a conocerlo a través de la enseñanza en los estudios básicos. Del reconocimiento de la cooficialidad del castellano y de la lengua propia de una Comunidad se deriva el mandato para los poderes públicos, estatal y autonómicos, de in- 
cluir en los Planes de Estudio ambas lenguas cooficiales como lenguas docentes y como materia de enseñanza obligatoria.

En modo alguno procede interpretar el bilingüismo como deber de conocer y usar la lengua vernácula, ni como una atribución a la Administración de la Comunidad Autónoma de la facultad de imponer la lengua de la Comunidad Autónoma en la enseñanza como lengua vehicular, negando el derecho a elección. La Constitución no deja margen a que el ordenamiento autonómico niegue el derecho de todos los españoles, a preferir el castellano en sus relaciones con los poderes públicos, el sistema educativo inclusive y en las relaciones entre particulares.

El carácter del catalán de lengua usual o habitual debe ser compatible con el uso asimismo normal del castellano tanto en la expresión por escrito de actos o avisos como en las relaciones entre privados. Un uso excluyente podría dar lugar a segregación por razones del lenguaje, cuando conforme a la Constitución nadie puede ser discriminado por razón de la lengua, mucho menos por razón de la lengua oficial del Estado.

La política lingüística de la Generalidad de Cataluña de fomento del catalán y de hostilidad hacia la lengua castellana, en la medida en que excluye u obstaculiza la libre elección entre los dos idiomas médula del modelo constitucional de bilingüismo, afecta a la propiedad privada, la libertad empresarial, la libertad de expresión y al derecho a la educación. Por todos los comentarios valgan a título de ejemplo 1) el dictamen de Francesc de Carreras, catedrático de Derecho constitucional de la Universidad Autónoma de Barcelona y miembro durante años del Consejo Jurídico de la Generalidad de Cataluña, sobre el control judicial de la política lingüística a efectos de la cooficialidad de castellano y catalán y de la libertad de elección de lengua, Francesc de Carreras Serra; José Domingo Domingo, La aplicación de la Ley catalana de Política lingüística: su Control judicial, Teoría y Realidad Constitucional, nums. 12-13, 2. ${ }^{\circ}$ semestre 2003-1er semestre 2004; y 2) los votos particulares de los Magistrados Diaz Eimil y Gabaldón a la STC 337/1994.

1) A juicio de Francesc de Carreras la Ley de Política lingüística establece un régimen de bilingüismo muy desequilibrado a favor del catalán que pone de manifiesto una voluntad monolingüe del legislador de la Generalidad. Los preceptos de la Ley de Política lingüística que definen el alcance del catalán como lengua propia, la lengua de las Administraciones de Cataluña y la lengua de los procedimientos administrativos tramitados por las Administraciones catalanas (arts. 2.2 a), 9 y $10 \mathrm{LPL}$ ) han sido objeto de recursos ante la justicia por su posible inconstitucionalidad. El Tribunal Superior de Justicia de Cataluña identifica la declaración del catalán como lengua propia con su carácter de lengua oficial en el territorio de Cataluña. Mediante tal tesis, el Tribunal desfigura el concepto de lengua propia al equipararlo al de lengua oficial, condición ésta que alcanza también a la lengua castellana en Cataluña. A juicio de Carreras ello debiera conllevar que ambas lenguas tuvieran el mismo status (art. 3 LPL) y no avala la preeminencia del catalán. A pesar de la claridad de la redacción del art. 9.1 LPL que excluye el uso del castellano en las relaciones internas y con los concesionarios de sus servicios, el Tribunal obvia la inconstitucionalidad con recurso a la posibilidad no excluída del derecho de los ciudadanos a recibir comunicaciones y notificaciones en castellano si lo piden (RJCA 2001/387).

El Tribunal Superior de Justicia de Cataluña recuerda no obstante que el Tribunal Constitucional ya se pronunció en contra del uso exclusivo de la lengua oficial de una Comunidad Autónoma en la STC 82/1996, declarando la inconstitucionalidad de la Ley 10/1982 del Parlamento vasco (Ley Básica de Normalización del Uso del Euskera).

Otro caso es la sentencia del Juzgado de Lo Contencioso-Administrativo núm. 13 de Barcelona, de 5 de diciembre de 2002 (caso Medidas para la regulación y fomento del uso del catalán, Junta de Gobierno de la Universidad Pompeu i Fabra). El Juez considera que el repliegue del castellano en Cataluña "estará sometido a límites infranqueables, debiendo quedar salvaguardada la oficialidad del idioma común del pueblo español con una intensidad suficiente como para garantizar su función integradora al servicio del principio de unidad ex art. 2 CE.

Según Carreras, los distintos órganos judiciales han optado por tesis conservadoras de la norma a la que tratan de dar coherencia constitucional tomando como referencia a todo el sistema jurídico. Con sus sentencias corren el riesgo de amparar las consecuencias prácticas discriminadoras del castellano que acarrean el contenido literal de la Ley de Política Lingüística. Los tribunales obvian intencionadamente la realidad social y fáctica sobre la que las normas se aplican. El catalán se convierte en la práctica en la lengua única de uso de las instituciones catalanas. Los tri- 
bunales conocen la realidad pero han optado por ignorar la voluntad del legislador catalán de obstaculizar la igualdad lingüística y eludir el debate. El actual marco normativo ampara un bilingüismo claramente desequilibrado en favor del catalán.

En los Reglamentos de los corporaciones locales y de las universidades se incide en el carácter propio de la lengua catalana y se omite cualquier referencia a la oficialidad de las lenguas, excepcionalmente, se recurre a una mera remisión al art. 3.2 EAC, que reconoce el carácter oficial de catalán y castellano, y se elude mencionar el art. 3.3 EAC, a cuyo tenor "La Generalidad garantizará el uso normal y oficial de los dos idiomas y... creará las condiciones que permitan llegar a su igualdad plena en cuanto a los derechos y deberes de los ciudadanos de Cataluña. Los tribunales demoran el enjuiciamiento de los excesos a la aplicación de los Reglamentos. De todos modos, una interpretación tan favorable a la conservación de las normas no ha podido sostenerse, procediendo los tribunales a la anulación o suspensión cautelar de determinados preceptos.

Según Carreras, de las distintas resoluciones judiciales analizadas se deduce el significado de catalán lengua propia de Cataluña como el principal elemento de controversia. Tal término figura solamente en el Estatuto de Autonomía de Cataluña no en la Constitución. Ciertamente, desde un punto de vista histórico-geográfico puede mantenerse que el catalán es la lengua propia de Cataluña. Ahora bien, la Ley de Política Lingüística le otorga la condición de lengua de sus instituciones y pretende convertirla también en lengua de sus habitantes. Ello parece a Carreras mucho menos aceptable por no avenirse con la realidad social; en efecto, las lenguas mayoritariamente utilizadas por los ciudadanos catalanes son tanto el castellano como el catalán. Incluso es mayor el porcentaje de ciudadanos que declaran considerar como lengua propia el castellano. La protección del catalán no debe anular los derechos lingüísticos de los ciudadanos. Es previsible que prosigan los conflictos judiciales mientras la normativa y las prácticas administrativas obvien tales datos de la realidad social y pretendan imponer la llamada lengua del territorio.

Los órganos judiciales catalanes han acudido a ejercicios de malabarismo jurídico para no cuestionar constitucionalmente la legislación y las prácticas de la Generalidad. Ello parece jurídicamente indefendible. A pesar de que la voluntad del legislador catalán es convertir al catalán en lengua oficial exclusiva y excluyente, jueces y tribunales han preferido ignorarlo. Los mismos no parecen dispuestos a asumir la carga de limitar los desafueros del Parlamento de Cataluña. Así, se han limitado a anular los preceptos reglamentarios en los que la voluntad monolingüe excluyente del castellano era especialmente notoria. Los conceptos "normalización lingüística", "discriminación positiva" y "pluralismo lingüístico" están arrumbando la libertad de elección, la cooficialidad de las lenguas y la conexión del Derecho con la realidad social.

2) Votos particulares a la STC 337/1994. Voto del Magistrado don Eugenio Díaz Eimil. Objeto del voto particular: el enjuiciamiento constitucional que merece la política de inmersión lingüística ordenada en la Ley de Normalización Lingüística, en la medida en que declara el catalán lengua vehicular de la enseñanza, imponiéndola como tal en la enseñanza no universitaria de manera obligatoria y sin solución alternativa que permita elegir el castellano como lengua docente.

A juicio del Magistrado Díaz Eimil, la mayoría yerra alterando la naturaleza del problema al desplazar el contencioso hacia el art. $27 \mathrm{CE}$ y, a partir de ahí, introducir criterios derivados del derecho a la educación que lo es solamente desde un segundo plano. Lo realmente planteado es un problema de cooficialidad lingüistica en el que no se debate de manera primaria los efectos limitadores de la lengua en la organización del sistema educativo, sino los límites constitucionales que las Comunidades Autónomas bilingües deben respetar en el ejercicio de su acción política de fomento lingüístico.

Los límites constitucionales que las Comunidades Autónomas bilingües deben respetar en el ejercicio de su acción política de fomento lingüístico debe determinarse desde el art. $3 \mathrm{CE}$, que es el que consagra el modelo de bilingüismo que acoge nuestra Constitución. Tal modelo constitucional completado por los Estatutos, establece los principios y derechos a partir de los que debe obtenerse la solución del problema, con independencia de cuál sea el ámbito administrativo o sector material sobre el que se proyecta la acción política.

El art. $3 \mathrm{CE}$, completado por el art. 147.1.17 CE y el art. 3 EAC, establece un modelo de cooficialidad lingüística en el que, respecto a las lenguas autonómicas, es pieza esencial el principio de libertad de elección. A tenor de tal principio, todo residente en una Comunidad Autónoma bi- 
lingüe tiene derecho a elegir, en sus relaciones con los poderes públicos, la lengua castellana como medio exclusivo de expresión lingüística. Por consiguiente, no puede imponérsele contra su voluntad el uso obligatorio del idioma autonómico.

Según el bilingüismo reconocido en el art. $3 \mathrm{CE}$, la cooficialidad de las dos lenguas - castellana y la propia de la Comunidad Autónoma- no significa sino la atribución de plena eficacia y validez jurídicas a las manifestaciones hechas en cualesquiera de los dos idiomas cooficiales. En modo alguno procede interpretar el bilingüismo como deber de conocer y usar la lengua vernácula, ni como una atribución a la Administración de la Comunidad Autónoma de la facultad de imponer la lengua de la Comunidad Autónoma en la enseñanza como lengua vehicular, negando el derecho a elección.

El art. 3 CE establece un tratamiento diferenciado entre el castellano y las lenguas autonómicas. Respecto de éstas no se declara el deber de conocerlas y usarlas, que se predica de la lengua castellana. El tratamiento diferenciado entre el castellano, lengua oficial del Estado, y las lenguas de las Comunidades Autónomas se estableció de forma deliberada en la Constitución: las Cortes rechazaron la enmienda núm. 106, que proponía el reconocimiento expreso del deber de conocimiento de las lenguas cooficiales distintas de la lengua castellana.

El art. 3 CE no deja margen a negar el derecho de todos los españoles a preferir el castellano en sus relaciones con los poderes públicos, incluido el sistema educativo-el derecho a recibir enseñanza en lengua castellana ha sido reconocido por el Tribunal STC 6/1982;

- el Tribunal niega que exista obligación constitucional de conocer las lenguas propias de las CC.AA. STC 84/1986;

- el Tribunal declara que la Constitución no impone el deber de conocer el idioma autonómico y que este deber no es inherente a la cooficialidad lingüística;

- el Tribunal reconoce a todos los ciudadanos el derecho a elegir con libertad real entre las dos lenguas cooficiales y legitima la enseñanza en vascuence por la voluntariedad de su elección.

Este modelo de cooficialidad lingüística, en el que el conocimiento y uso de las lenguas autónomas se rige por el principio de libre elección encuentra su complemente en el art. 3 EAC, conforme al cual, para cumplir el deber de garantizar el uso normal y oficial del castellano y del catalán se impone a la Generalidad la obligación de adoptar las medidas necesarias para asegurar su conocimiento y crear las condiciones que permitan alcanzar las condiciones de igualdad en lo que se refiere a los derechos y obligaciones de los ciudadanos de Cataluña.

Con el art. 3 EAC se cierra el modelo constitucional de cooficialidad lingüística. A su tenor, el derecho de conocer y usar el catalán se corresponde con la obligación de la Generalidad de llevar a efecto la política lingüística que permita a los ciudadanos satisfacer ese derecho, si libremente optan por ejercerlo. En cumplimiento de esa obligación, la Generalidad tiene amplios márgenes para proyectar y realizar las medidas que considere convenientes en orden a generalizar y profundizar el conocimiento y uso del catalán, No existe obstáculo constitucional para, además de incluir la enseñanza del catalán en los planes de estudio, establecer un sistema educativo en el que se utilice el catalán como lengua vehicular de la enseñanza. Ahora bien, la Generalidad deberá siempre proveer un sistema educativo alternativo que permita a los ciudadanos y residentes en Cataluña que así lo prefieran, elegir la lengua castellana como lengua docente exclusiva.

En atención a ello, la inmersión lingüística que se articula en la Ley 7/1983 es inconstitucional en cuanto desconoce y niega el derecho a recibir la enseñanza en la lengua oficial del Estado.

El Tribunal Constitucional yerra al admitir el deber de usar el catalán como lengua vehicular de la enseñanza. Ello subvierte el modelo constitucional de bilingüismo al transmutar la obligación de la Generalidad de satisfacer el derecho a conocer el catalán, en la potestad de imponer su conocimiento y uso con carácter obligatorio. De ese modo el Tribunal reconoce a la Generalidad convertir lo que es un derecho de conocimiento del catalán en un deber de conocerlo y usarlo, sin alternativa alguna. El Tribunal destruye, así, el principio de libertad de conocimiento y uso de las lenguas autónomas, que es el núcleo del modelo de cooficialidad lingüística.

El Tribunal debería, más bien, haber reconocido a todos los ciudadanos y residentes en Cataluña el derecho a elegir el castellano como lengua vehicular de la enseñanza y vedado que se imponga el catalán como lengua docente de obligado uso.

Voto particular del Magistrado don José Gabaldón López. 
güística de la Generalidad de Cataluña, en la medida en que afecta, por supuesto, a la libertad de empresa y a los derechos de usuarios, consumidores e inversores, pero asimismo al ejercicio del resto de derechos y libertades y, por

1. El art. 27.1 y 2 en relación con el art. 3.1 CE definen un derecho a recibir la educación no solo en el idioma propio de la Comunidad Autónoma sino asimismo en castellano como lengua oficial del Estado.

No cabe hablar de un derecho a la educación, si no puede establecerse el vehículo esencial a través del cual todo saber ha de transmitirse, o sea el lenguaje. El derecho a la educación supone, pues, el de recibirla en un lenguaje que sea suficientemente conocido... en aquel idioma del país donde la educación se recibe, puesto que los centros educativos están en todo caso sometidos a las reglas de la oficialidad lingüística establecida.

2. Cosa distinta es, sin embargo, el derecho a recibir la enseñanza en lengua que se conozca y a cuyo uso se tenga derecho e incluso obligación; es decir, en una de las lenguas que son cooficiales en cada Comunidad Autónoma. El derecho a recibir la instrucción en lengua que se comprenda completa su contenido con el derecho a que sea aquella que configura el derecho de los ciudadanos a conocerla y usarla.

El Tribunal ha reconocido tal derecho: tras señalar que los órganos centrales del Estado tienen competencia exclusiva para "regular las condiciones básicas que garanticen la igualdad de todos los españoles en el ejercicio de los derechos y en el cumplimiento de los deberes constitucionales, entre los cuales se encuentra el de conocer la lengua del Estado" (STC 6/1982), el Tribunal afirma que la Alta Inspección puede ejercerse legítimamente para "velar por el respeto a los derechos lingüísticos y en particular el de recibir enseñanza en la lengua del Estado".

Al señalar "la obligación que tienen todos los españoles de conocer el castellano" — solo del castellano se establece constitucionalmente un deber individualizado de conocimiento y, con él, la presunción de que todos los españoles lo conocen-, se reconoce que «el Estado puede regular... las garantías básicas de la igualdad en el uso del castellano como lengua oficial... así como las garantías del cumplimiento de deber de conocimiento del castellano, entre las que se halla la obligatoriedad de la enseñanza en ese idioma (STC 6/1982).

3. Si el art. 3.1 CE establece el deber de conocer la lengua castellana y el derecho fundamental a la educación exige que la enseñanza, dentro de España se reciba en un idioma comprensible para el alumno pues, de no ser así, no queda eficazmente prestado, es evidente que en el contenido del derecho a la educación se comprende el de recibirla en la lengua de quien ostenta ese derecho. Por el art. 14 CE nadie puede ser discriminado en la enseñanza por razón de la lengua, mucho menos por razón de la lengua oficial del Estado.

Ambas lenguas oficiales han de ser empleadas como lenguas docentes y también como materia de enseñanza (SSTC 87/1983; 88/1983), pues al no hacerlo se incumpliría el art. 3 CE.

7. El art. 3.3 EAC establece que la Generalidad garantizará el uso normal y oficial de los dos idiomas. El que los centros de enseñanza "deban hacer" de la lengua catalana vehículo de expresión normal en todas sus actividades, tanto internas como de proyección externa, ha de reputarse como una prescripción legítima siempre que el mandato no se convierta en un obstáculo real para el uso habitual de la lengua cooficial; es decir, que "expresión normal" sólo indique el carácter de lengua usual o habitual, pero no única ni menos excluyente del castellano para que no se convierta en una barrera previa a la necesaria integración de todas las personas. Ese carácter de lengua usual debe ser compatible con el uso asimismo normal del castellano tanto en los actos o avisos que hayan de expresarse por escrito como en las relaciones personales. Un uso excluyente podría dar lugar a separación por razones del lenguaje.

Cfr. Asimismo, Tomás Ramón Fernández, Dictamen emitido a requerimiento de diversas asociaciones sobre la conformidad a la Constitución de la Ley catalana de Política lingüistica, de 7 de enero de 1998; Sebastián Martín Retortillo, Dictamen sobre si la Ley catalana 1/1998 de Política lingüística es o no conforme con el bloque de la constitucionalidad; Miguel Herrero Rodríguez de Miñón, Dictamen en derecho, a petición del Gobierno de la Generalidad de Cataluña, sobre la Constitucionalidad de la Ley catalana 1/1998 de Política lingüística todos ellos en Teoría y Realidad Constitucional, núm. 2, 1998. 
ende, a los intereses generales. El problema se centra en los límites constitucionales que las Comunidades Autónomas bilingües deben respetar en su política lingüística. Los mismos vienen determinados por el modelo de cooficialidad lingüística en el que es central el principio de libertad de elección. A su tenor, todo residente en una Comunidad Autónoma bilingüe tiene derecho a elegir, en sus relaciones con los poderes públicos y entre particulares, la lengua castellana como medio de expresión lingüística; lo cual excluye que quepa imponérsele el uso del idioma autonómico. Con la Ley de Inmersión Lingüística, de 1993, la Generalidad ha transgredido tales límites. La Ley de Política Lingüística, de 1998, agravó más aún si cabe la situación. La imposición del catalán como lengua preferente destierra al castellano como lengua normal. La obligación por ley para los poderes públicos de diseñar la toponímica sólo en catalán atenta contra la cooficialidad del castellano. La prescripción de uso del catalán para los medios de radiodifusión y televisión públicos, los medios de comunicación escritos, las empresas públicas, los servicios públicos, las empresas concertadas o subvencionadas, la atención al público, en la medida en que están orientadas a constreñir la expresión en castellano, atentan contra la cooficialidad. Tales mandatos se extienden, además, a las relaciones entre particulares. Respecto de las mismas — documentos civiles y mercantiles, usuarios de servicios públicos, consumidores e inversores, sin ir más lejos_- la Ley de Política lingüística atenta contra la libertad de empresa y los derechos de usuarios, consumidores e inversores. La política de fomento del catalán, con el envés de hostilidad hacia la lengua castellana, en la medida en que excluye u obstaculiza la libre elección entre los dos idiomas, afecta a la libertad empresarial, la libertad de expresión, las relaciones entre privados y al derecho a la educación. En este caso, no se trata, como en los supuestos más arriba referidos, sin embargo, tanto de una limitación de los derechos de propiedad privada y libertad empresarial cuanto, justo, de una garantía constitucional para los mismos de la libertad de elección del idioma a emplear en el tráfico jurídico.

No hay que identificarse con el sector conservador del espectro político - a lo que parece, éste no es mi caso_- para apreciar que la Generalidad ha dedicado un empeño digno de mejor causa a poner toda suerte de trabas al uso del castellano en Cataluña. En la España moderna y contemporánea, nunca antes habían sido tan reconocidos culturas, lenguas y símbolos regionales como bajo la Monarquía Parlamentaria. Y, sin embargo, cuantiosas quejas de los ciudadanos y alguna que otra cuestión de constitucionalidad por razón de los obstáculos para el uso del castellano en Cataluña han saltado al foro público, acumulándose en el registro de entrada de los juzgados, del Defensor del Pueblo y del Tribunal Constitucional. Que hasta ahora no se hayan traducido en declaraciones de inconstitucionalidad de la legislación idiomática de la Generalidad se explica menos porque la relación lingüística de los ciudadanos con la Administración pública y entre particulares discurra conforme a la Constitución, que por la presión política y mediática en y desde Cataluña, cuya clase política no acepta la igualdad bajo el Derecho con el resto de Es- 
paña y no se para en barras, para hacer de aquélla en asuntos de su especial interés un territorio extramuros de nuestra Carta Magna. Dado que la lengua castellana como lengua española oficial del Estado es una condición material para el ejercicio de las libertades, la hostilidad institucional hacia su práctica en Cataluña atenta contra los derechos ciudadanos y, por ende, contra los intereses generales. La clase política y los medios de Cataluña deben saber que la igual libertad de todos y los intereses generales no están a disposición. La diversidad territorial y cultural es, incluso en la España federal de mañana, también un bien público a garantizar, pero solamente realizable como subfunción de la igual libertad de todos como bien público superior.

Un ramillete de conclusiones se ha ido avanzando al paso de mi exposición sobre los intereses generales.

1. El espacio material de lo público. Los derechos fundamentales como principios objetivos del ordenamiento, los límites al derecho de propiedad privada y a la libertad empresarial y los principios rectores de la política social y económica son, en cuanto elementos de los intereses generales, tres figuras jurídicas ciertamente autónomas pero ligadas causalmente entre sí y con equivalentes efectos jurídicos. Conjuntamente, la tríada de figuras delimita el espacio material de lo público, que el constituyente ha querido acorazar frente a veleidades de las mayorías parlamentarias. El núcleo esencial de lo público que una sociedad precisa indispensablemente para realizarse en segura e igual libertad (Hegel) no puede depender de la coyuntura. Con ellos, el constituyente quiso acotar un espacio constitucional al abrigo de todo decisionismo, en el que, protegidos de las dependencias respecto de los poderes económicos y mediáticos, sea posible a los ciudadanos vivir en libertad.

2. La imagen del hombre en la Constitución. Tal tríada de figuras ensambla los bienes públicos que los españoles identifican como patrimonio con la Constitución. En su conjunto, expresan la imagen del hombre (Häberle) ${ }^{38}$ condensada en el art. 10.1 CE. En ese sentido, previenen, de un lado, contra una interpretación exclusiva de los derechos fundamentales en términos de derechos subjetivos de defensa frente al Estado. Por otro, refuerzan el ordenamiento contra mayorías legislativas que, so pretexto de la libertad de circulación de capitales y de la libre competencia comunitarias (TCE), pudieran sentirse tentadas a dar al traste con tales garantías. Vienen, así, a sancionar una cierta condición irrevocable del Estado social, ya que a ningún gobierno cabe boy día incumplir las tareas de procura, previsión y compensación sociales, como ha escrito el maestro Konrad Hesse, o el principio de irregresividad, en términos de nuestro Tribunal Constitucional ${ }^{39}$. El esfuerzo concretador del constituyente y su apuntalamiento de las grandes conquistas sociales tienen la virtud de servir de muro de contención frente al despliegue arrollador del mercado en la configuración de nuestras existencias.

38 vid., Peter Häberle, Das Menschenbild im Verfassungsstaat, Berlin: Duncker \& Humblot, 1988.

39 vid., Konrad Hesse, Grundzüge des Verfassungsrechts der Bundesrepublik Deutschland, 20., neubearbeitete Auflage, Heidelberg: C. F. Müller Verlag, 1995. Cfr. sobre Principio de irregresividad STC 134/1987). 
3. Revalorización de nuestra tradición constitucional. No deberían los lectores interpretar mi lección de hoy, sin embargo, en el sentido de que reserve a los Estados la realización de los intereses generales. Sería un planteamiento de cortos vuelos, habida cuenta no sólo de la ampliación y de la jerarquía de las fuentes del Derecho ${ }^{40}$, sino también de la mundialización de la economía y de las condiciones de existencia. Las mismas muestran que, precisamente, a la hora de realizar los intereses generales, el Estado tropieza con los límites de su acción. No es así posible dentro de las fronteras españolas proveer a todos los bienes públicos señalados: es el caso del medio ambiente, de la inmigración, de la estabilidad monetaria, de la fiscalidad, del abastecimiento de energía, en fin, de la seguridad y de la paz. De ahí que el planteamiento requiera indispensablemente de una perspectiva europea y mundial.

Las figuras mencionadas corporeizan la alternativa pública de nuestra Constitución al Tratado de la Comunidad Europea, de diseño orientado a la competitividad y al mercado, desproporcionadamente privatizador ${ }^{41}$. El Jürgen Habermas de Facticidad $y$ Valide $z^{42}$ se sentiría dichoso de saber hasta qué extremo la Constitución española refleja su paradigma de la conexión intrínseca entre autonomía pública y autonomía privada.

Si el nuevo Tratado que, para el año 2009, nos anuncian nuestros príncipes pretende conseguir la adhesión de la ciudadanía, deberá hacer de las tradiciones constitucionales comunes el norte del Derecho europeo y del Derecho internacional. En tal sentido, el postulado de la Constitución española de la primacía de los intereses generales aspira con toda justificación a servirle de architrave.

\section{EPÍLOGO}

Permítame el lector cerrar con unas palabras personales. Siempre he visto en nuestra Constitución una maravillosa síntesis del legislador romano, del sabio griego y del ideal emancipatorio del profeta judío. No se extrañe, pues, de que la haya querido tanto. Yo desperté a la vida buscando el diálogo con la generación de 1914. Ellos me dejaron en herencia una suerte de sueño, la España de ciudadanos igualmente libres del futuro, que desde entonces espera ser hecha realidad. De Manuel Azaña, Julián Besteiro, Américo Castro y Luis

40 Sobre la modificación de las fuentes del Derecho STC 166/1986. En la doctrina por todos, vid. J. Alguacil González-Aurioles, La Directiva comunitaria desde la perspectiva constitucional, Madrid: Centro de Estudios Constitucionales y Políticos, 2004.

41 vid. A. López Pina, Derecho europeo y principio constitucional de igualdad. El Tratado de la Unión ante la prueba de las tradiciones constitucionales, en id., La Constitución territorial de España. El orden jurídico como garantía de la igual libertad, Madrid: Marcial Pons Ediciones Jurídicas, 2006.

42 Cfr.: Jürgen Habermas, Faktizität und Geltung, Frankfurt am Main: Suhrkamp, 1992. Hay version en lengua española de Editorial Trotta. Sobre el particular vid., A López Pina, Del procedimiento como fundamento moral, Saber / Leer, núm. 73, Madrid: Fundación Juan March, 1994. 
Jiménez de Asúa a Salvador de Madariaga, Manuel Pedroso y Fernando de los Ríos, sin olvidar, faltaba más, José Ortega y Gassett ${ }^{43}$, me legaron su idea de España: por una parte, fundada en la educación y el trabajo; por otra, magnánima hasta el extremo de abrazar y dar morada en solidaridad y respeto a todos los españoles e inmigrantes igualmente libres. Tallar en Derecho tal idea de España de la generación de $1914^{44}$ ha sido la ilusión de la generación de 1956 a la que pertenezco.

El enfrentamiento actual de la oposición con el Gobierno, hasta el extremo de cuestionar la legitimidad de los resultados electorales de 2004 y de escenificar aquelarres semejantes a los que hasta ahora sólo cultivaban los identitarismos catalán y vasco, lleva a la exacerbación la lucha desnuda por el poder de los partidos. Los efectos negativos de tal encono se ven potenciados por el hecho de que, sin límites ni escrúpulos, algunos medios de difusión contribuyen diariamente a una descalificación popular de los políticos democráticamente elegidos. Nunca desde 1977 he tenido como ahora la impresión de que estamos bordeando la violencia. Antes de la guerra civil Francisco Ayala y, más recientemente, Böckenförde se han planteado en qué medida cabe al Estado de Derecho dotarse de garantías de la propia eficacia ${ }^{45}$. La Monarquía Parlamentaria española es un caso arquetípico de hasta qué extremo una Constitución progresista puede cambiar el destino histórico de una sociedad ${ }^{46}$. Sin embargo, garantías de naturaleza cultural extramuros del Derecho como el espíritu de tolerancia, la civilidad, la razón, la sensibilidad para las instituciones y los intereses generales o la virtud pública, bien se nos dan ex origine y la clase política los asume como noble tradición, o, en otro caso, su misma carencia condena a la impotencia la acción benéfica del Derecho. La vigencia

43 vid. A. López Pina, Lo público. Hacia la recuperación del discurso ilustrado español (1914-1936), Debate Abierto, núm. 10, homenaje a Carlos Ollero, 1994; Luis Gómez Llorente, En torno a la confesionalidad de la escuela, Cuadernos de Pedagogía, núm. 50, Abril 2004; id., Un consenso laborioso y necesario, Cuadernos de Pedagogía, núm. 329, Noviembre 2003; id., El valor de la Igualdad, en Un futuro para la Izquierda. 20 años de Izquierda Socialista, Madrid: Biblioteca Nueva, 2002; id., Vigencia del Laicismo, Temas para el Debate, Noviembre 2001; id., Escuela pública: el libre pensamiento. Una reflexión actual en torno a Condorcet, Cuadernos de Pedagogía, núm. 307, Noviembre 2001; id., La participación y la educación ético-cívica, en Una alternativa progresista. Educación de calidad, Madrid: Fundación Pablo Iglesias, 2001; id., Educación y Ciudadaní, Madrid: Colectivo Lorenzo Luzuriaga, 15 Junio 2000; id., Principios de la Escuela Pública, en Por la Escuela Pública. Homenaje a Mariano Pérez Galán, Madrid: Fundación Educativa y Asistencial CIVES, 1998; id., Alternativa socialista a la Enseñanza, conferencia pronunciada en el Club Siglo XXI, Madrid: Secretaria de Organización Federal del PSOE, 1979; Antonio García Santesmases, Laicismo, Agnosticismo, Fundamentalismo, Madrid: Biblioteca Nueva, 2006.

44 Cfr., Sobre la Generación de 1956, F. Bustelo, La izquierda imperfecta, Barcelona: Planeta, 1996; D. Jato, La rebelión de los estudiantes. Apuntes para una historia del alegre SEU, segunda edición, Madrid: 1969; A. Lago Carballo, A. Una nueva Generación entra en escena, Madrid, 1956; P. Lizcano, La generación del 56. La Universidad contra Franco. Barcelona: Grijalbo, 1981. 45 Vid. F. Ayala, Presentación, de la obra Teoría de la Constitución, de Carl Schmitt, en edición de 1934; publicada en Madrid: Alianza Editorial, 1982; E.-W. Böckenförde, Gewissensfreiheit, Vereinigung der deutschen Staatsrechtslebrer, 28/33, 80 Berlin: Walter de Gruyter Verlag. 46 Vid. A. López Pina, La Constitución territorial de España, op. cit. 
de la Constitución termina a la postre siendo rehén de los rasgos culturales regresivos que caracterizan a nuestra política actual.

Colocados de nuevo al borde del enfrentamiento civil, el hermoso mito de España bajo el Derecho, de la generación de 1914, que ha cobrado forma en la Constitución de 1978, se encuentra bajo asedio. Como a todos ustedes, a mí no me deja indiferente el destino de tanta grandeza. Estando aún a tiempo de salvar el orden constitucional amenazado, ¿seremos capaces de enderezar el actual curso? Pendientes de los recursos de inconstitucionalidad contra los Estatutos de Autonomía y, en su caso, del eventual conflicto entre el derecho al trabajo y los Acuerdos con la Santa Sede, el Tribunal Constitucional nos tiene en vilo. A ningún poder es lícito pretender una patente de corso frente a los intereses generales. Y la verdad es que, para obsequiarnos con un par de grandes sentencias sobre el principio de igualdad, la cooficialidad de la lengua castellana en Cataluña, el equilibrio territorial y el derecho al trabajo y restablecer, así, la primacía de los intereses generales, nuestros Magistrados no carecen, precisamente, de un espejo en el que mirarse: de la jurisprudencia de un cuarto de siglo y de la doctrina del Consejo de Estado, descuellan con especial brillo las figuras ejemplares, como dogmáticos, de Luis Díez-Picazo y Jesús Leguina y, por su espíritu institucional y alto sentido del Estado y del Derecho, de Manuel García Pelayo, Francisco Tomás y Valiente y Landelino Lavilla. En sensibilidad para la cuestión social, ninguno de ellos se queda a la zaga. Que a nadie le tiemble el pulso: emergentes movimientos ciudadanos en elecciones autonómicas, el distanciamiento popular respecto de los referenda de Cataluña y Andalucía y pronunciamientos diarios en el foro público expresan a las claras, negro sobre blanco, que mayorías de ciudadanos, ahítas de frustraciones con la política, nada ansían más que el Derecho refleje los intereses generales y les devuelva la paz civil perdida.

Con el cambio de siglo, la generación de 1956 ha pasado a la reserva. Ahora bien, que nadie piense que una España federal, en una Europa de vocación cívica universal, sea un proyecto a la defensiva de solo un puñado de viejos constituyentes. Está simplemente a la espera de que, con voluntad de Constitución ${ }^{47}$ y a paso de olimpíada, una legión de ciudadanos recoja el testigo y devuelva a España y a Europa la primacía de los intereses generales bajo los grandes ideales de la Ilustración.

ABSTRACT. In this article the author meditates on the main problem of our societies, on which Tocqueville already pointed out what can be made so that in popular government's equitable society governs the empire of the law and not the despotism. Our architecture constitutional part of the private autonomy but this freedom can only reconcile with the freedom of the others ones when it is limited through the public interest. The author explains it with several examples.

47 Vid. Konrad Hesse, Grundzüge des Verfassungsrechts der Bundesrepublik Deutschland, 20., neubearbeitete Auflage, Heidelberg: C. F. Müller Verlag, 1995 Rdn 41-44. 